See discussions, stats, and author profiles for this publication at: https://www.researchgate.net/publication/272390181

There's no beer without a smoke: Community cohesion and neighboring communities' effects on organizational resistance to antismoking regulations in the Dutch hospitality industry

Article in The Academy of Management Journal · February 2015

DOI: $10.5465 / \mathrm{amj} .2014 .0379$

CITATIONS

6

3 authors:

(2) Tal Simons

Erasmus University Rotterdam

19 PUBLICATIONS 1,213 CITATIONS

SEE PROFILE

Joris Knoben

Radboud University

74 PUBliCATIONS 1,305 CITATIONS

SEE PROFILE

Some of the authors of this publication are also working on these related projects:
READS

614

Patrick A.M. Vermeulen
Radboud University
83 PUBLICATIONS 1,998 CITATIONS

SEE PROFILE

Project Co-ordinated Case Studies - Enabling Innovation and Productivity Growth in Low Income Countries (EIP-LIC) View project

Project $\quad$ Organizations and Ideology View project 


\title{
THERE'S NO BEER WITHOUT A SMOKE: COMMUNITY COHESION AND NEIGHBORING COMMUNITIES' EFFECTS ON ORGANIZATIONAL RESISTANCE TO ANTISMOKING REGULATIONS IN THE DUTCH HOSPITALITY INDUSTRY
}

\author{
TAL SIMONS \\ Tilburg University \\ PATRICK A. M. VERMEULEN \\ JORIS KNOBEN \\ Radboud University Nijmegen
}

\begin{abstract}
This study highlights the importance of communities in explaining organizational resistance to institutional pressures. Examining the active resistance of small bars to smoking regulations in 427 Dutch municipalities (communities), we argue that the likelihood of organizational resistance to institutional pressure from a powerful actor is affected by the social cohesion of the focal community. In addition, we propose a contiguity effect that emphasizes the broader social context of the community-its neighboring communities-as a source for support or information about appropriate ways to resist such pressures. By incorporating community attributes to account for organizations' heterogeneous responses to institutional pressure, the study advances current institutional scholarship and demonstrates empirically how such a theory can help explain the success of relatively weak organizational actors' resistance in the face of strong institutional pressures by the state-that is, as a result of their embeddedness in a community.
\end{abstract}

\section{INTRODUCTION}

In line with the European Union (EU)-wide policy ultimately to attain a smoke-free Europe, the Dutch government has expanded its tobacco regulations in recent years, including the implementation of a ban on smoking in bars that took effect in July 2008. While proponents of smoking regulations have had to fight

We would like to thank Linus Dahlander, associate editor, and three anonymous reviewers for their insightful comments. We would also like to thank Ana Aranda, Andac Arikan, Royston Greenwood, Michael Lounsbury, Marc Schneiberg, Pamela Tolbert, and participants of the Lugano Conference on Organizations 2013, for their valuable comments on previous versions of this paper. The usual disclaimers stand. We also thank Steffie Jansen, Carin van der Cruijsen, Maarten Mulder, and LocalFocus for their assistance in data collection. An earlier version of the paper was presented at the 2012 Academy of Management Annual Meeting in Boston, and was the recipient of the Organization and Management Theory division's Best International Paper and the Academy of Management's Carolyn Dexter awards. All authors contributed equally to this paper. hard and long against big interests (e.g., tobacco growers and tobacco companies), today, there's a general agreement that the campaign has been quite successful, at least in some parts of the world (Wolfson, 2001). The implementation of a smoking ban in bars, however, has ignited fierce opposition among many in the Netherlands (Nagelhout, van den Putte, de Vries, Crone, Fong, \& Willemsen, 2011). Foremost among those opposing the new smoking regulations as they pertained to bars completely banning smoking were small bar owners, who joined the "Save the Small Bars" (SSB) foundation, a lead resistance association. Although not all small bar owners resisted the smoking ban, a large group did-and did so actively. Moreover, in some regions in the Netherlands, resistance was much fiercer compared to other regions. In this study, we seek to understand the resistance by small bars to institutional pressure emanating from a powerful actor, and argue that their embeddedness in more cohesive communities significantly sparked and contributed to their resistance, resulting in a David-versus-Goliath scenario.

In this paper, we build on earlier research studying the relation between institutional pressures and 
organizational responses (e.g., Doshi, Dowell, \& Toffel, 2013; Goodstein, 1994; Ingram \& Simons, 1995; Okhmatovskiy \& David, 2012; Oliver, 1991). Previous studies have emphasized the effect of the nature of the pressure (Oliver, 1991), organizational attributes (Elbannan \& McKinley, 2006; Okhmatovskiy \& David, 2012), industry attributes (Elbannan \& McKinley, 2006), location (Lounsbury, 2007; Marquis \& Lounsbury, 2007), cost-benefit considerations (Chatterji \& Toffel, 2010), political dependence (Marquis \& Qian, 2014), isomorphic pressures (Edelman, 1990; Okhmatovskiy \& David, 2012), and regional influences (Doshi et al., 2013) on this relationship. Yet, one particular type of response-resistance-is not commonly examined (however, see Marquis \& Lounsbury, 2007, and a few studies on institutional work such as Marti \& Fernandez, 2013; Quirke, 2013). A focus on resistance to institutional pressures is important because, despite resistance being key to understanding strategic responses to institutional pressures (Oliver, 1991), inadequate attention has been devoted to the "resistance of individuals and organizations to fieldlevel rules, norms and beliefs" (Lawrence, 2008: 179). Despite the recent emphasis on competing logics and conflict (Fiss \& Zajac, 2004; Lounsbury, 2007; Thornton \& Ocasio, 1999), and studies on the countermobilization efforts by aggrieved actors to protect their jurisdictions and established practices in the face of change (Davis, McAdam, Scott, \& Zald, 2005; Kim, Shin, Oh, \& Jeong, 2007; Levy \& Scully, 2007; Lounsbury, Ventresca, \& Hirsch, 2003), scholars have "not examined resistance per se” (Marquis \& Lounsbury, 2007: 800).

Additionally, recent studies in institutional theory have emphasized the role communities play in driving organizational activities (Almandoz, 2012; Doshi et al., 2013; Greenwood, Magan-Diaz, Li, \& Lorente, 2010; Greenwood, Oliver, Sahlin, \& Suddaby, 2008; Lounsbury, 2007; Marquis \& Lounsbury, 2007), highlighting the need to further investigate the intersection between communities and local organizations. Previous community studies in sociology have mainly looked at the role of communities and cohesion in relation to crime, poverty, friendship ties, social participation, social isolation, and a variety of socioeconomic outcomes (e.g., Coleman, 1988; Moody \& White, 2003; Putnam, 2000; Sampson, 1988, 1991; Small, 2002), but did not include organizations in their studies. Community studies utilizing a population ecology perspective have incorporated organizations into their analyses, but have predominantly studied the impact of local market conditions and communities on organizational population dynamics (e.g., Carroll \& Wade,
1991; Freeman \& Audia, 2006; Greve, 2002). In institutional theory, the influence of communities on organizations has been demonstrated in relation to a range of different outcomes, such as corporate philanthropy (Guthrie, Arum, Roksa, \& Damaske, 2008; Marquis, Glynn, \& Davis, 2007), corporate strategy (Lounsbury, 2007), new foundings (Almandoz, 2012), or the adoption of new practices (Davis \& Greve, 1997), and have focused in most cases on large corporations (or their headquarters), such as mutual funds (Lounsbury, 2007), banks (Marquis \& Lounsbury, 2007), Fortune 1000 firms (Tilcsik \& Marquis, 2013), and a variety of other U.S. corporations (Guthrie et al., 2008).

We depart from these studies by focusing on small, community embedded organizations that resist institutional pressure coming from a powerful state actor. We posit that the community is a nexus of socialinteractional and institutional mechanisms. Because we are interested in resistance, which, compared to other forms of organization behavior, requires a certain level of common values as a fuel for action, we chose to theoretically focus on community cohesion first and foremost. While doing so, we will not ignore, in the analyses, other community characteristics, whether examined in the past or not, that may affect organizations in it. In line with Marquis and Battilana (2009: 286), we conceptualize communities as "the populations, organizations, and markets located in a geographic territory and sharing, as a result of their common location, elements of local culture, norms, identity, and laws." Local communities often maintain shared frames of references that affect various outcomes, including organizational behavior (Brint, 2001). For example, Bielefeld and Corbin (1996) demonstrated that communities' "political culture" exerts institutional pressures via funding decisions and thus influences the configuration of non-profit organizations across communities, while Schneiberg, King, and Smith (2008) showed that some community characteristics help sustain capacities for resisting corporate dominance. Studies have also examined how variations in the characteristics of the embedded organizations result in their differing responses to community-level institutional pressures (Greenwood et al., 2010; Henriques \& Sadorsky, 1996).

However, knowledge about community-level influences on organizational responses to institutional pressures remains somewhat scarce (see also Marquis \& Battilana, 2009). Accordingly, we aim to uncover how organizational resistance is facilitated, affected, and sustained by community characteristics. Our theory highlights two factors that we argue affect the likelihood of organizational resistance to institutional 
pressure: one relates to the social fabric, or community social cohesion, that is created among individuals within a certain geographical locale, while the other adds another layer as it considers the contiguity effects that bring to the fore the broader social context of the community. We reason that while, when studying communities, we should pay close attention to how the relative stability of their social makeup and shared sense of belonging, common values, and destiny affect organizations' resistance, we should also not overlook that communities are influenced by neighboring communities, too, especially in the face of a common threat. Hence, the search for clues for an appropriate response is not limited to the community where a given organization resides, but extends beyond the boundaries of the locale to neighboring communities (more than to remote ones). Further, similar organizations facing the same institutional pressure and are located in different but proximate communities will cooperate in their resistance.

Our study's contributions are thus twofold; first, it contributes to institutional theory by examining the role of a community-level attribute in influencing the behavior of organizations. To date, scant attention has been directed at the actual effect of community processes on organizations embedded within the community. We not only look inside the community to analyze organizations' responses to institutional pressures, but also consider the broader social context of the community - its neighboring communities-as a source for signals, clues, or information about appropriate ways to encounter a problem. Second, we focus on a type of organizational behavior that is infrequently studied: resistance. Moreover, we consider it in the context of small organizations, whereas most of the existing literature on organizational resistance seems to concern larger, powerful firms (Drope \& Hansen, 2006; Elbannan \& McKinley, 2006). We show how the resistance of small organizations with limited resources has led to a situation in which a powerful actor, the state, was unable to impose the adoption of new legislation. As a whole, our research contributes to a layered and more nuanced investigation of institutional processes with a particular emphasis on the counterintuitive viability of small organizations in the face of a powerful institutional actor.

\section{RESEARCH CONTEXT}

More than half a million people die every year in the European Union as a direct or indirect consequence of smoking (European Commission, 2007). As a result, many EU countries have introduced smoking control policies. In general, the underlying reasons for promoting smoking-free environments and the resulting practice of smoking bans are far from being considered contentious among either professionals or the broader public opinion. The tobacco control movement has educated the public about the health risks of tobacco use, attempted to change social norms, and advanced the development of policies discouraging the use of tobacco. In contrast, the tobacco industry has long denied the harmful consequences of smoking and has persistently tried to influence legislators accordingly (Wolfson, 2001).

The efforts of the tobacco control movement have been targeted at the prevention of tobacco use and its related health risks, and at the protection from exposure to secondhand smoke (Wolfson, 2001). The movement has initiated smoking-cessation programs, launched information and education campaigns, and endeavored to influence the development of policies related to indoor air quality, youth access to tobacco, and advertising. At the same time, a countermovement of industry manufacturers and others who benefit from the production of tobacco was mobilized to contest some of the critiques. The Tobacco Industry Research Committee, for example, has recruited and funded more than 1,000 academics and other researchers to conduct studies that might cast doubt on the relation between smoking and health issues (Wolfson, 2001).

Despite the power of the tobacco industry, though, the tobacco control movement in Europe has been able to partly achieve its goals. Smoking rates have decreased from $60 \%$ to about $25 \%$ among adults in most European countries, albeit with considerable variance; Sweden, Iceland, Slovenia and Portugal all were found to have less than $20 \%$ of the adult population smoking, versus Greece (40\%) and Bulgaria and Ireland (30\%) (OECD, 2010). However, smoking continues to be a habit that has not been eliminated, and that many around the continent still engage in on a daily basis. Furthermore, although several countries have implemented a variety of smoking control policies and bans, most "have built comforting loopholes into their antismoking laws," thus resulting in only a small decline in the consumption of cigarettes following the introduction of smoking bans (Spinney, 2007: 1507). Moreover, about a third of Europeans (but, again, with quite a variance across countries) are totally opposed to enforcing a smoking ban in bars or pubs.

\section{The Netherlands}

In 2002, the Dutch parliament altered the Tobacco Act to require smoke-free workplaces and public 
transportation, and strengthened enforcement provisions. After intensive lobbying by the hospitality industry, parliament passed an amendment with the understanding that the hospitality industry would be initially exempted, and smoke-free environments phased in over time (Gonzalez \& Glantz, 2011: 4). In January 2004, the smoke-free workplace legislation was implemented in all industries except the hospitality industry (Nagelhout et al., 2011).

STIVORO (Stichting Volksgezondheid en Roken; the main tobacco control organization in the Netherlands) and three Dutch non-governmental health organizations (NGOs) joined forces and decided to integrate lobbying into their tobacco control activities. In 2006, the health NGOs and STIVORO developed a policy agenda that included ending the Tobacco Act's hospitality exemption, raising tobacco taxes, requiring that health insurance plans cover tobacco-use cessation, and increasing government spending on tobacco control. They expanded their smoke-free coalition to include Clean Air Netherlands (CAN) and other groups. During the November 2006 election campaign, the smoke-free coalition lobbied to include their policy package in the new government's post-election agenda (Gonzalez \& Glantz, 2011: 4). At the same time, the hospitality industry and its allies opposed the smoke-free regulations, arguing they would lower demand, reduce profits, and ultimately cost jobs (e.g., Horeca Nederland, 2008; Synovate, 2008).

Throughout 2007, the hospitality industry as well as smokers' rights organizations continued to oppose ending the industry's exemption from the general smoking ban by courting media attention (Gonzalez \& Glantz, 2011: 5). A recent study showed that most newspaper coverage at the time was negative toward the smoking ban (57\%), and had a small but significantly negative effect on support for smoke-free bars and restaurants (Nagelhout et al., 2011). Hospitality organizations, individual venue owners, and the Dutch employers' association complained to parliament and the media that the then Minister of Health (Ab Klink) was not working with them and that he had failed to consider the SSB's proposal that the laws be phased in gradually between 2008 and 2011. Minister Klink also investigated the possibility of incorporating ventilation (i.e., separate smoking rooms) as an alternative to implementing smoke-free laws, but eventually rejected this option (Gonzalez \& Glantz, 2011: 5). The government decided to implement smoke-free legislation for the hospitality industry from July 1, 2008 (Nagelhout et al., 2011), thereby rejecting the SSB's phase-in proposal, with the result that all hospitality venues would be subject to the same regulation.

\section{Decreasing Compliance}

The Dutch Food and Consumer Product Safety Authority (Voedsel- en Warenautoriteit; VWA) was put in charge of enforcing the law and taking measures against bars that violated the smoking ban. Bars could receive fines of up to 2,400 Euros, a significant amount for businesses of this size. In addition, bars that violated regulations repeatedly would face criminal prosecution, and eventually be shut down. In a study of 6,742 hospitality venues, it was found that $5 \%$ of all organizations received official warnings due to non-compliance; 750 of these venues were bars, of which $37 \%$ received an official warning (VWA, 2008). The VWA also published a report on the degree of subsequent compliance for the 2008-2010 period (VWA, 2010), during which time, initially, most hospitality venues that were inspected seemed to comply. Yet, some differences among various types of venues could already be seen to be emerging. Of the bars and discotheques that were inspected ( 100 in total), $76 \%$ complied with the new legislation, whereas compliance among other hospitality venues, such as restaurants, hotels and sports facilities, ranged from $94 \%$ to $100 \%$. The noncompliant organizations contended that they were experiencing economic losses, and continued to violate the regulations (Gonzalez \& Glantz, 2011). In a letter to parliament, Minister Klink reported that, from October 1 to December 1, 2008, the VWA visited 2,800 bars, 1,200 violations of the law were reported, and 821 organizations were fined. By early 2010 , only $59 \%$ of all bars were complying with the smoking ban.

According to the SSB, the associated economic losses bars were experiencing following the smoking ban were the main reason for not complying with it. The Minister of Health commissioned the governmental statistical agency (Centraal Bureau voor de Statistiek; CBS) and TNS NIPO (a market research firm in the Netherlands) to analyze prices, sales volume, sales trends, and revenue growth, as well as consumer confidence to evaluate the SSB's claims (Gonzalez \& Glantz, 2011: 9). The CBS found that the declining sales in bars were due to a myriad of factors: prices, weather conditions, the economy, and consumer confidence. The main conclusion of the agency's study was that there was no direct connection with the smoking ban. The study conducted by TNS NIPO arrived at similar conclusions. However, 
small bar owners and their allies persisted in their claims of economic losses, and parliamentary members continued to petition Minister Klink to review alternatives to smoke-free regulations and to respond to questions regarding the relation between the decrease in proceeds and the introduction of the smoking ban (which some members of parliament portrayed as irresponsible behavior by the Minister) throughout 2009. The Minister promised to continue monitoring economic developments in the hospitality industry. However, questions were also posed concerning the social function of bars in local communities, with Member of Parliament and former Minister of Immigration and Integration Rita Verdonk specifically asking Minister Klink:

What do you think of the fact that this will be the end of a large number of small neighborhood bars? Do you think this has a harmful effect on the social cohesion within communities?

—(Aanhangsel HAN TK, 2008-2009, nr. 1867)

\section{THEORY AND HYPOTHESES}

Institutional theory has moved away from earlier concerns with isomorphism and conformity in the face of institutional pressures toward an understanding of social systems as fragmented and contested arenas in which conflicting principles and values enacted in discourse and action are more likely than coherent sets of desired principles and values (Dyck \& Schroeder, 2005; Fiss \& Zajac, 2004; Hoffman, 1999; Lounsbury, 2007; Rao, Morrill, \& Zald, 2000). Efforts toward understanding the contested and indeterminate nature of institutional processes build on earlier work to address criticism against institutional theory for focusing on the effects of the institutional environment on structural conformity while overlooking the role of interest and agency in organizational adaptation to institutional environments (Greenwood \& Hinings, 1996; Oliver, 1991). Responding to institutional pressures may confront actors with unfamiliar tasks, intensify institutional contradictions, and entail the need to redraw the connections between sets of practices and the moral and cultural foundations for those practices (Slack \& Hinings, 1994; Thomas \& Davies, 2005).

Oliver (1991) was among the first to develop a framework for institutional resistance, or, as recently defined by Lawrence (2008: 171), "attempts of actors to impose limits on institutional control and institutional agency." Fox-Wolfgramm, Boal, and Hunt (1998) noted the potential for institutional resistance by examining the differential strategic responses of two Texas-based banks to new regulation. Both banks resisted the institutional pressure associated with the new regulation, but did so in different ways because of a lack of congruence between the regulation and the banks' strategic orientations, identities, and images. While resistance is often portrayed as a key but little-understood strategic response to institutional pressures, more research is needed on the processes and mechanisms through which some actors derive the power to resist and contest institutional pressures while others acquiesce to them (Marquis \& Lounsbury, 2007). Marti and Fernandez (2013) studied the extreme case of the Holocaust to try and analyze underlying mechanisms stimulating resistance, and found that, while resistance rarely occurs and, when it does, it is often not very successful, sometimes, mundane efforts of resistance can lead oppressed populations to confront systems of oppression. Outside of such extreme contexts, though, it would be fruitful to further examine under what conditions organizations resist institutional pressures.

Other studies in institutional theory have highlighted geographical differences that drive organizational activities (e.g., Lounsbury, 2007; Marquis \& Lounsbury, 2007). Accordingly, we contend that organizations' resistance should be studied while taking into account these geographical differences, and that it is specifically organizations' embeddedness in communities, which varies with respect to a fundamental community attribute, social cohesion, that will differentially affect their resistance. Mindful that organizations, and their focal community, are embedded in a broader social context, we also theorize a contiguity effect of neighboring communities on the aforementioned level of resistance.

\section{The Role of Communities}

Studies in the ecological tradition (Freeman \& Audia, 2006) and in the economic geography literature (Torre \& Gilly, 2000) have long argued that geographical proximity brings organizations together, furthers interaction with considerable information richness, and facilitates the exchange of knowledge (especially tacit knowledge) between actors, all of which ultimately results in a shared interpretation and common understanding of various stimuli. Geographic regions exhibit overarching qualities that make them durably distinct (Molotch, Freudenburg, \& Paulsen, 2000). In institutional theory, communities have attracted renewed attention, not simply because of the significance of geographical 
boundaries but also because of the conceptualization of communities as institutional orders (Greenwood et al., 2010; Marquis \& Lounsbury, 2007; Marquis, Lounsbury, \& Greenwood, 2011). As Greenwood et al. (2010: 535) noted:

Analytical abstraction, intended to better capture contextual influences, has resulted in a relative blindness to how communities (regions) and their interaction with state logics affect organizations. The relationship between communities and organizations, informed through an ideology of the state, was integral to early institutional work, but that focus has largely disappeared. A return to the traditional emphasis upon community would be timely.

Consequently, geographic communities in which organizations are embedded are considered to be an important source of institutional pressures (Marquis \& Battilana, 2009; Marquis et al., 2007). Marquis and Battilana (2009) claimed that communities have an enduring influence on the behavior of organizations, arguing that, in addition to variations in laws, local market characteristics, and institutional mechanisms could also explain differences in organizational behavior across communities. For example, Molotch et al. (2000) examined the differing ways in which two Californian urban areas, Ventura County and Santa Barbara County, dealt with external development projects (specifically, the alternative approaches local actors took in dealing with phenomena over which they had only partial control but that would have significant effects on both sites: an oil development and a freeway project). The authors found that the distinct character and tradition of each community determined its response to outside pressures. Similarly, Marquis et al. (2007) posited that institutional forces within a specific community would have an effect on the nature and level of corporate social practices; that is, local understandings, norms, and rules may serve to legitimize corporate social action. Davis and Greve (1997) illustrated this effect in their study on the adoption of "golden parachutes," which were more quickly adopted by locally headquartered companies in some cities than in others, depending on relative standards of appropriateness. Guthrie's (2003) and Useem's (1988) studies also illustrated the existence of community-based norms and attitudes, while Waldorff and Greenwood (2011) found that communities have distinct sociocultural histories that generate important differences. In their study on Danish municipalities, the latter authors found that health care provision in local health care centers "varied across municipalities despite a national commitment to universal access to the same level and quality of service" (Waldorff \& Greenwood, 2011: 136). Greenwood et al. (2010) demonstrated that there are strong community effects on organizational decisions related to the generation of profits, and Almandoz (2012) showed the impact of community logics on the success of establishing new banking ventures. Collectively, these studies suggest a powerful effect of geographical communities on organizational behavior.

However, there have been only a few attempts to understand the impact of communities in explaining resistance to institutional pressures. Lounsbury (2007) showed that competing logics among different communities shaped variation in the behavior of distinct groups of actors (mutual funds in Boston resisted the aggressive strategies of New York funds). Marquis and Lounsbury (2007), too, found that variation in resistant behavior could be related to geographical differences. Their study focused on community-level actors that operated with local community logic "to protect local autonomy in the face of outsiders' impositions of national logics over multiple geographic regions" (Marquis \& Lounsbury, 2007: 800). Thus, it seems that community-level attributes, and in particular those relating to the social fabric of the community, may spur organizations to resist certain pressures. By incorporating community-level attributes into the study of resistance, we move away from the more instrumental nature of strategic responses and follow the suggestions of Oliver (1991) and Marquis and Lounsbury (2007) to understand resistance as being socially structured.

We consider two major factors in predicting resistance to regulatory pressures: (1) social cohesion and (2) the prevalence of resistance in neighboring communities. First, we ask whether a community's degree of social cohesion has an impact on organizations residing and operating in it. The idea of social cohesion and its consequences is central to sociology (e.g., Durkheim, 1897/1951; Tönnies, 1887/1957), including a specific focus on community cohesion (e.g., Brint, 2001; Sampson, 1991; Sampson, McAdam, MacIndoe, \& Weffer-Elizondo, 2005). In an illuminating review of the concept of social cohesion, Friedkin (2004) highlighted its multiple definitions, or "definitional confusion," suggesting that this is a result of the complexity of the reciprocally linked individual- and group-level nature of the phenomenon (see also Chan et al., 2006). Addressing the vast literature of social cohesion is 
not our goal here, though; rather, we propose to build on some of the earlier work of social cohesion in general (Festinger, 1950; Friedkin, 2004) and community cohesion in particular (Almandoz, 2012; Marquis \& Battilana, 2009; Portes \& Sensenbrenner, 1993; Uzzi, 1996) to reason that a community's degree of cohesiveness will have an effect on the focal community's organizations' resistance to externally instigated institutional pressures.

Social cohesion is often presented as a multidimensional concept (Chan, To, \& Chan, 2006; Friedkin, 2004; Kearns \& Forrest, 2000), and in this study we focus on two key dimensions, residential stability and kinship, as "the building-blocks of social cohesion reside within places" (Kearns \& Forrest, 2000: 1001). Furthermore, these two dimensions map respectively onto an analytical distinction common in cohesion research between the relational and ideational components, which, however, "does not imply causal precedence of one dimension over the other" (Moody \& White, 2003: 104). As we explain in detail below, each dimension operates via a different mechanism in contributing to the eventual organizations' action in the face of institutional pressure: residential stability fosters a latent relational infrastructure, while kinship generates a sense of belonging and care about the community.

We also consider how resistance in a given community is dependent on a contiguity effect-that is, the influence of neighboring communities. Communities are part of a larger social context of adjacent communities that affect a focal community through the movement of symbolic and physical resources across communities' boundaries (Lamont \& Molnar, 2002). Extending a classical argument in institutional theory, the likelihood of resistance increase when communities geographically proximate to a focal community show a high level of resistance, due to mimetic processes triggered by environmental pressures (DiMaggio \& Powell, 1983). We postulate that, furthered by mobilization and collective action by similar organizations in neighboring communities, similar organizations actively assist one another in the face of common threat.

\section{Community Cohesion: Residential Stability}

Identification with a collectivity and connections among members of the collectivity refer respectively to the ideational and relational dimensions of cohesion, which might mutually reinforce each other (Moody \& White, 2003). Simply put, the "relational dimension" refers to the connections or relationships among the collectivity's members, which, we posit, are to a large extent a consequence of residential stability. In developing this argument, we reiterate the prominent focus on membership continuity and turnover that was a feature of early works on social cohesion (e.g., Festinger, Schachter, \& Back, 1950) and remains salient in later research (e.g., McPherson \& Smith-Lovin, 2002), maintaining that residential stability has "direct positive effects on local social ties, which in turn increase the level of community social cohesion" (Sampson, 1991: 47). Moreover, as explained below, community social cohesion promotes a community's ability to "solve common problems."

In communities where the turnover of residents is relatively low, there is a greater likelihood that the relational facet of cohesion will develop through the interplay of building connections over time among the community's residents (Kearns \& Forrest, 2000). As shown, for example, in Kasarda and Janowitz's (1974) study, residential stability has positive and highly significant direct effects on almost all types of local social bonds, and particularly noteworthy is its strong effect on the number of acquaintances in the community. In other words, residential stability facilitates many contact points and provides opportunities for people to live side by side, get in touch with each other, and spend time in the same places (Chaskin, 1997), resulting in a latent relational infrastructure. Borne out of the daily functioning of residents within their community, these connections are "latent" in that they are not necessarily acted on, manifested, or exploited on a regular basis (see a similar point made by Starkey, Barnatt, \& Tempest, 2000: 300, with respect to organizations). Thus, individuals residing together in a community over time enables the formation of many "unused ties" (Mariotti \& Delbridge, 2012). Such a state of affairs can remain in place for an indeterminate period, but, when faced with a common enemy or external interference, adverse pressure, or threat, this basic latent relational infrastructure will allow fast mobilization of the community. This proclivity has been referred to as "collective efficacy," which "is meant to signify an emphasis on conjoint capability for action to achieve an intended effect, and hence an active sense of collective engagement on the part of residents to solve problems" (Sampson et al., 2005: 676).

In view of this, we posit that the then newly introduced anti-smoking ban posed an external threat, challenge, or "common problem" to be resolved (cf. 
Sampson, 1991) to a community as important local organizations (Lashley, 2000) serving social, cultural, as well as economic functions were threatened. In such situations, local communities and their organizations react defensively, aiming for a strict "conservation of their space" (Castells, 1997: 62). And, while all small bars in the Netherlands faced the same regulations and occupied significant social roles in their respective communities, the residential stability levels of the affected communities varied. It is therefore expected that, in communities exhibiting greater residential stability, the resulting latent relational infrastructure will be more developed and readily available for mobilization in the face of the common threat, and these at-risk organizations' owners and residents will be more likely to join forces in actions aimed at preserving and defending the preferred cultural and economic status-quo against the new regulations or other similarly adverse institutional pressures. Accordingly:

Hypothesis 1. Communities with a high degree of residential stability will have more bars resisting the smoking ban, compared to communities with a low degree of residential stability.

\section{Community Cohesion: Kinship}

While the section above focused on the relational dimension of social cohesion emanating from residential stability, here we focus on a sense of identification with and belonging to-a collectivity that we refer to in this study as "kinship." Kinship is the sentiment, sense, or feeling that bonds residents to a specific place-community-and generates commitment and a responsibility for the residents to take care of it. A community's social cohesion in this sense results from the positive effect that a strong sense of belonging, or attachment to a place and residents' identities intertwining with that of the place, has on notions such as adherence to common values and norms, the salience of past experiences, and common ideas and culture (Kearns \& Forrest, 2000). The presence of a sense of belonging to the community is valuable in supporting residents' acknowledgment of their collective circumstances, and, thus, their motivation for collective action (Chaskin, 1997). A common understanding among residents concerning their preferences for various aspects of the community's guiding vision, everyday functioning, and long-term viability will thereby be established. Furthermore, a sense of belonging to a community and kinship are claimed to be conducive to the development and cementing of mutual obligation among not only individuals but also the organizations and businesses sited in the community. Such a community, it is argued, will be more likely to stick together in the face of threats to its values and norms (Lamont \& Molnar, 2002) even when this would conflict with "any sense of common national purpose” (Forrest \& Kearns, 2001: 2128).

The campaign against the smoking ban was framed in economic and social language focusing on the economic hardships, but also (significantly, for the purposes of our study) on the smoking ban as undermining bars' "community function." Ton Wurtz, cofounder of the SSB, declared: "A small bar in Holland has a social function and what you are doing is that you rip that out of the society through this stupid law" (Stichting Horecaclaim Nederland, 2009). Bars are considered to play "an important role in defining the identities of groups, communities, and societies, and in defining the relationship between individuals and the wider social context" (Lashley, 2000: 8-9). Through the "consumption of food and drink, and the rituals and norms associated with that, individuals express their connectedness or disconnectedness with the wider community" (Lashley, 2000: 9). Specifically, in the Netherlands, "gezelligheid" (literally, sociability and conviviality) is a core value that is "exercised" in local bars and supersedes an array of other values, reinforcing the bars' central social function in local communities, as expressed in the SSB representative's assertion above. We anticipate that it is the varying strength of kinship that exists among communities, though, that will, owing to relative levels of mutual obligation and caring, differentially influence the extent to which bars will resist the anti-smoking bans. Thus:

Hypothesis 2. Communities with a higher level of kinship will have more bars resisting the smoking ban, compared to communities with a low level of kinship.

\section{Community Contiguity: Resistance in Neighboring Communities}

A focal community is not an isolate. Every community is embedded in an environment consisting of other, adjacent communities, and we consider that this broader social context affects the focal community through the movement of symbolic and physical resources across communities' boundaries (Lamont \& Molnar, 2002). That is, through these resource flows across communities' boundaries, adjacent 
communities influence various aspects of one another. Sociologists who have studied disadvantaged communities, focusing on outcomes such as violence rates or child maltreatment, have found a strong effect of contagion across proximate communities, effects that hold independent of a myriad of the focal community's characteristics (Coulton, Korbin, Su, \& Chow, 1995; Morenoff, Sampson, \& Raudenbush, 2001).

In this study, we build on the above-noted notions and findings, but postulate somewhat different dynamics, involving a contiguity effect between adjacent communities with respect to resistance levels, and arguing, as we explain below, that this contiguity effect varies with the focal community's level of social cohesion (in terms of both residential stability and kinship) due to the latter's effect on boundary permeability. The contiguity effect is driven by the ambiguity and uncertainty experienced by the organizations with respect to what the best course of action is. Given the disparity between the actors' power and the issue at hand, the bars in our study faced a real predicament: their survival was threatened either way, as they risked losing customers if they complied with the smoking ban or severe sanctions if they did not, including fines, prosecution, and closure in case of repeated offenses. Following similar others who are facing the same circumstances and are proximate can be thought of as a mimetic response to such uncertainty (DiMaggio \& Powell, 1983: 151), and also as a "safety in numbers" strategy (Hedström, 1994: 1163).

For small bars located in Dutch communities, mimetic behavior was a plausible response to the uncertain situation they found themselves in when facing the new smoking ban regulations. Here, the behavior being imitated was (active) resistance to the smoking bans. ${ }^{1}$ Conceptually, the greater the number of organizations in nearby communities that display a certain type of behavior, the more likely it is that organizations in the focal community will behave similarly. Leicht and Jenkins (1998) argued, for example, that geographic mimetic pressures from adjacent states had a positive effect on the adoption of public venture capital programs. Furthermore, especially in the case of contentious practices (such as resisting a smoking ban), it is likely that significant consistency of organizations' behavior within proximate communities will

\footnotetext{
${ }^{1}$ Since surrounding communities might exhibit various levels of either resistance or compliance, it can be argued that compliance is also being imitated. However, for the purpose of this study, we are interested primarily in resistance.
}

be visible, salient, and influential (Davis \& Greve, 1997). Relatedly, but highlighting a different aspect of following others, mimetic responses may provide valuable signals and information about the actual implications of choosing a certain course of action (Hedström, 1994), or that the risks associated with an action that involves significant costs may be mitigated as the number of actors choosing it increases.

In addition to and reinforcing the mimetic dynamics among organizations located in proximate communities, we maintain that, when the organizations involved are small and relatively powerless, active cross-community boundary collective action and mobilization are more likely to occur. Neighboring communities are likely to be more "institutionally proximate," which means they share cultural norms and habits to some degree allowing for coordinated action between organizations in these communities (Boschma, 2005). Hence, similar organizations facing comparable pressures, constraints, and threats to their viability have an incentive to share information, warn against impending inspections, and collaborate with others in neighboring communities to successfully resist that significant threat. Naturally, such actions are easier to perform with organizations in proximate communities, as compared to organizations in distant communities (see Zukin \& DiMaggio, 1990). Thus, in the context of our study, we posit:

Hypothesis 3. Communities that share borders with communities that exhibit high levels of resistance will have a higher number of bars resisting the smoking ban, compared to communities that share their borders with communities with low levels of resistance.

A key property of boundaries is that they are permeable, but this permeability is variable and contingent (Lamont \& Molnar, 2002). In our study, we expect resistance levels in neighboring communities to interact with both dimensions of community cohesiveness—residential stability and kinship—as more cohesive groups are also characterized by more impervious boundaries, and are thus less open or receptive to information, ideas, and values coming from others who are not a part of the group (Janis, 1982) or are located beyond the group's boundaries (Lamont \& Molnar, 2002). Residential stability implies less in-flow of ideas and influences from outside, and refers to the "physical permeability" of a community boundary: ideas from the outside arenot "physically carried in" by new entrants. Organizations in communities with a high degree of residential stability may not look beyond the 
boundaries of their community due to lock-in (e.g., Boschma, 2005), and may be less open to opportunities and resources outside of their own community (Knoben \& Oerlemans, 2012). Research concerning the Swiss watch industry showed that such network rigidities had a negative effect on the ability of the sector to respond to external pressures, causing the partial collapse of the Jura region's competitive position (Glasmeier, 1991). Consequently, we expect that the effect of resistance in neighboring communities will be weaker in communities that experience a reduced in-flow of ideas and influences due to lesser movement of residents across shared boundaries. Hence:

Hypothesis 4. The effect of the level of resistance in neighboring communities is weaker in communities exhibiting greater residential stability.

As a community's level of kinship increases, its normative framework becomes more salient and entrenched, such that it is less amenable to ideas or other influences coming from beyond its boundaries, regardless of the nature of these ideas. Communities with high levels of kinship, and, by extension, the organizations located in them, will be less prone to learn from others or collaborate (again, independent of what those positions, actions, or sentiments are). Moreover, high degrees of kinship tend to create more trust between insiders and less trust in outsiders. Such insider-outsider distinctions may "foster parochial narrowmindedness" and are considered a potential downside of communities (Bowles \& Gintis, 2002: F428). In a study on territorial agglomerations of firms, the effect of trust on innovation was found to be negative when the degree of localized trust led firms to collaborate with organizations they were already familiar with rather than with firms they did not know (Molina-Morales \& Martínez-Fernández, 2009). In our study, referring to the "cognitive permeability" of a community boundary, we expect that a strong sense of belonging to a particular community and the accompanying normative framework will limit the utilization of ideas, norms, and values from beyond the focal community's boundary. That is, whatever the community's position is on a certain issue, the more cohesive it is, the less likely it will be influenced by external sentiments or behaviors. Thus:

Hypothesis 5. The effect of the level of resistance in neighboring communities is weaker in communities exhibiting higher levels of kinship.

\section{RESEARCH METHODS}

\section{Qualitative Findings}

We collected qualitative data to obtain a better understanding of the small bar owners' motivations for resisting the smoking ban. Since they were facing a large powerful actor that was actively enforcing the new law, we wanted to know the reasons for resistance and gain a better overview of their actions and the underlying mechanisms that triggered these actions. In addition, we wanted to understand the positions of various stakeholders (such as bar patrons (smokers and nonsmokers), trade associations, politicians, and anti-smoking lobby groups) concerning the smoking ban. Two main data sources were used: newspaper articles and telephone interviews.

For the newspaper articles, we relied on the Lexis/ Nexis database. The law came into force on July 1, 2008, but the heated public debate surrounding the ban had started months earlier, and therefore our search covers the whole of 2008. We used "smoking ban" as our search string in all Dutch newspapers (national and regional), which generated more than 3,000 results. After Lexis/Nexis automatically deleted articles with strong similarities, we were left with 958 newspaper articles. A further round of deleting articles with moderate similarities resulted in 706 newspaper articles. We then started reading these articles and further reduced the number to 563, deleting articles that referred to smoking bans in other countries. This final set of articles was downloaded and relevant quotes were saved into a separate file.

Nineteen interviews were conducted with small bar owners in order to better understand the context of small bars and to identify reasons and motives for their resistance (to the ban) and its nature. These interviews were conducted by phone in 2012 and were subsequently transcribed. Although the smoking ban had been effected in 2008, the bar owners could vividly remember what they did after the law was implemented. Small bars were still resisting the ban in 2012, and there were several lawsuits from small bars filed against the state challenging the various requirements the regulations imposed on them, which implied the issue was still unresolved. Table 1 presents an overview of the demographics of the bar owners we interviewed and their reasons for resistance/compliance and subsequent actions.

The quotes from the newspaper articles and telephone interviews reflected opinions of the bar owners and a variety of stakeholders, and were 
TABLE 1

Demographics of Bars

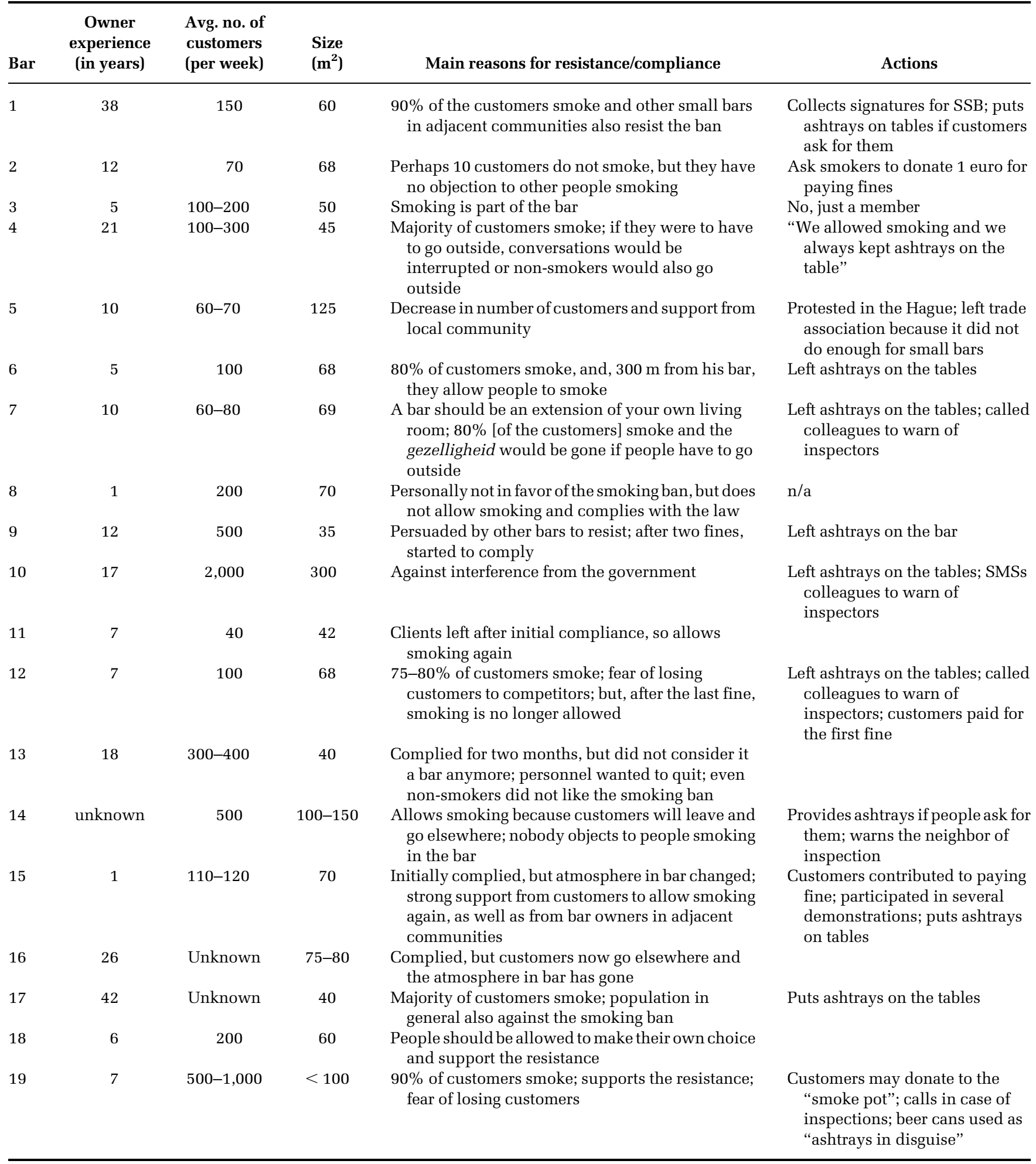


sorted into the key mechanisms we identified: latent social ties, kinship, willingness to act, and collaboration across communities (see Table 2). Latent social ties referred to the bars having an important social function in the community as a place where people meet, talk, and socialize. ${ }^{2}$ Small bars were supported by their customers, both smokers and non-smokers, to resist the law, and they also voluntarily donated money to pay for non-compliance fines. We noticed that small bars and their customers considered themselves to be part of a "family." Nonsmokers also frequently complained about their friends having to smoke outside, as it spoiled the atmosphere in the bar (as expressed in Table 2). Invoking the notion of a family and identification with smokers by their non-smoking friends highlighted the kinship felt among owners and patrons, smokers and non-smokers alike. There was also evidence that bar owners looked outside the boundaries of their community to collaborate with bar owners in neighboring communities. This was observed through reference to specific actions undertaken when inspectors showed up (calling or texting their colleagues to warn them) or discussions concerning what to do with the smoking ban and a collective decision to resist. Latent ties, kinship, and collaboration with other bar owners triggered a strong willingness to act on behalf of the small bar owners. This willingness to act was also visible from the point of view of bar owners who did comply with the law, who mentioned that their colleagues who resisted were sometimes threatening toward them (see Table 2).

In addition, we looked for quotes that referred to specific actions taken by bar owners, to better understand the nature of their resistance. There were three general types of actions: (1) symbolic actions, (2) monetary actions, and (3) actions against inspections (see Table 3). Symbolic actions often sidestepped the law by changing the nature of the establishment. For instance, some bars claimed to be a member of the Universal Church of Smokers from God. They changed their statutes and thereby members were officially practicing religion in their church (i.e., the bar) by worshiping the holy trinity of smoke, ash, and fire (see also Table 3). Alternatively, since the law was partly aimed at providing a smokefree workplace, a bar could claim to be a "self-service"

\footnotetext{
${ }^{2}$ We acknowledge that these examples pertain to manifestations of the latent social infrastructure in reaction to the strong institutional pressure on the communities. By definition, the underlying latent social infrastructure is very difficult to empirically observe.
}

bar, which then implied there was no personnel needed and so smoking could be allowed (bars without employees were, at that point, exempted). Others created a smokers' association that had members who were only in the bar for formal meetings. The agenda of these meetings included topics such as the color of pencils and the shape of beer mats, and, when they were held, all members had to attend, which again implied that there was no personnel needed. In addition to such circumventions, bar owners' monetary actions involved asking for donations or giving customers the opportunity to voluntarily donate money to pay any non-compliance fines incurred, while actions against inspectors mainly comprised alerting colleagues by calling or texting them. Moreover, some bar owners published pictures of inspectors on the Internet so that they could be easily recognized by other bar owners, and, since most small bars have a regular group of bar patrons, "outsiders" might now also be identified as inspectors (see Table 3).

\section{Quantitative Hypothesis Testing}

In order to test our hypotheses, we gathered and combined quantitative data from several sources. Below, we describe these data sources and the computations used to construct the measures for each of our variables. Before doing so, however, we should first address the operationalization of our level of analysis: the community. Given that we defined communities as the populations, organizations, and markets located in a geographic territory and sharing, as a result of their common location, elements of local culture, norms, identity, and laws (Marquis \& Battilana, 2009), municipalities were the logical geographical entities to use in the Dutch context. ${ }^{3}$ Dutch municipalities are relatively small geographical units that coincide with cities or towns and their surrounding environment. They have their own local elections and autonomous governments, and many laws that are relevant to pubs and bars,

\footnotetext{
${ }^{3}$ The number of such municipalities fluctuates slightly over the years, due to administrative mergers. Given that not all of our data sources pertain to the same year, these fluctuations need to be resolved. Therefore, we used the municipal classification of 2010 for each of our measures. In this year, the Netherlands comprised 431 municipalities. After dropping the 4 largest urban municipalities (Amsterdam, Rotterdam, the Hague, and Utrecht) for reasons that are explained below, we have 427 observations in our statistical analyses.
} 
TABLE 2

Mechanisms Driving Bars' Resistance

\begin{tabular}{|c|c|c|}
\hline Mechanism & Stakeholders & Representative quotes \\
\hline & Customers & $\begin{array}{l}\text { "Yeah, when it just started, I must admit, I think that our regular customers, } \\
\text { and also those that were not regular, they supported us. We had a 'smoke pot' } \\
\text { and it was completely voluntary, we had no rule that they had to donate. But } \\
\text { many people were happy that we resisted. They were very willing to } \\
\text { donate." }\end{array}$ \\
\hline \multirow[t]{2}{*}{ Kinship/sense of belonging } & Customers & $\begin{array}{l}\text { "I come here for the gezelligheid. If all smokers go outside, I will be here all by } \\
\text { myself. I have asked the bar owner if my friends could please smoke again." }\end{array}$ \\
\hline & $\begin{array}{l}\text { Publisher of Rookvrij } \\
\text { [Smoke Free] }\end{array}$ & $\begin{array}{l}\text { "The social aspect goes a long way, so I have noticed. The owner is family and } \\
\text { the bar patrons are your best friends. There are pets, they save money for } \\
\text { a joint social event and the glass with your name on it is stored and locked at } \\
\text { night when the bar closes. As an outsider, you do not enter easily. You might } \\
\text { actually wonder how pubic these bars actually are." }\end{array}$ \\
\hline \multirow{2}{*}{$\begin{array}{l}\text { Collaboration between bar } \\
\text { owners across communities }\end{array}$} & Bar owners & $\begin{array}{l}\text { "No, they figured that out quickly. So, they, for instance, would not first check } \\
\text { the entire village, but would inspect a bar here and then, in the next village, } \\
\text { another bar. So, they found out quickly. But we continued calling our } \\
\text { colleagues [to warn] that they just visited us." (Bar owner, telephone } \\
\text { interview) }\end{array}$ \\
\hline & & $\begin{array}{l}\text { "We are here in a circle of three villages with three bars. And all three had the } \\
\text { same ideas regarding the smoking ban." (Bar owner, telephone interview) }\end{array}$ \\
\hline \multirow[t]{2}{*}{ Willingness to act } & Bar owners & $\begin{array}{l}\text { "I am more or less being intimidated by my colleagues because I refuse to put } \\
\text { the ashtrays back on the table." (Bar owner) }\end{array}$ \\
\hline & & $\begin{array}{l}\text { "If every bar owner would put in } 50 \text { Euros, we could hire a lawyer with that } \\
\text { money, like they do in Tilburg [city in the south of the Netherlands]. The } \\
\text { fines that we get, we can fight these, and, for now, not pay them." }\end{array}$ \\
\hline
\end{tabular}

such as those regarding opening hours and patio permits, are determined at the municipality level. Moreover, municipalities exhibit high levels of economic homogeneity and social cohesion (Tolsma, van der Meer, \& Gesthuizen, 2009), and are relatively homogenous in terms of the norms and beliefs of their population (van Tubergen, te Grotenhuis, \& Ultee, 2005). As such, they serve as an excellent operationalization of the concept of communities as we have defined them, and have been used as such in prior policy (Plantinga, de Ridder, \& Corra, 2011), economics (Knoben, Ponds, \& van Oort, 2011), and sociology studies (van Tubergen et al., 2005).
However, the above arguments in support of their use in our research context are less applicable to the municipalities that contain the country's biggest cities. In these cities, the bars and pubs, especially those in the city center, don't serve the local community but instead cater primarily to tourists. Moreover, different rules and regulations often apply to pubs and bars in different parts of those cities (e.g., there are specific rules and regulations for pubs in the red light district in Amsterdam). Finally, these big cities are economically and socially much more heterogeneous than smaller communities. Based on these considerations, we opted to exclude the four municipalities (out of a total of 431 
TABLE 3

Bar Owners' Responses

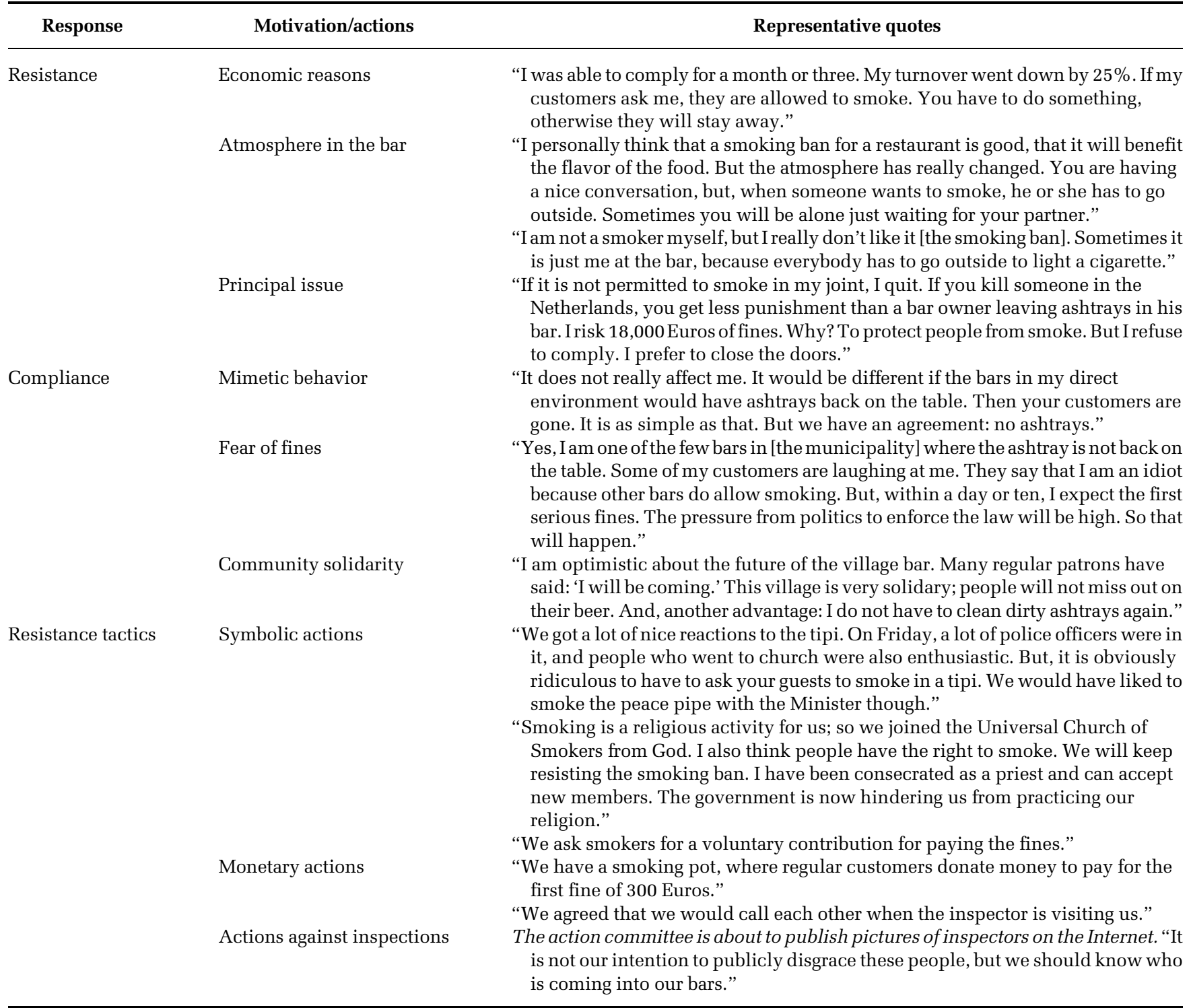

municipalities) that contain the four largest cities of the Netherlands.

\section{Data Sources and Measures}

Dependent variable. To measure the resistance to the smoking ban, we used the membership files of the SSB foundation at the end of 2008. These membership files contained the names and addresses of pubs and bars that openly stated that they were against the smoking ban, and, in almost all cases, allowed smoking on their premises, even though doing so represented violating the law at the time. Based on the address information of these pubs, we could determine in which municipality the bars were located. This information was used to calculate our dependent variable, the number of bars in the municipality appearing on the member list of the SSB.

To validate our measure of resistance to the smoking ban, we used data on the number of fines that were given to bar owners for violating the smoking ban. These data were not made public by the inspection agency (VWA) for a long time. In June 2014, however, a newspaper won a government transparency lawsuit that forced the VWA to disclose most of this information. They did not disclose 
the names of the bars that were fined, but did disclose the municipalities in which the fined bar was located. On the basis of this information, we calculated the number of fines per municipality for the period 2008-2009. One problem associated with this measure was that the same bars were often fined multiple times, whereas other bars were never inspected and therefore not fined at all. Nonetheless, we expected a substantial correlation between the number of members of the SSB foundation and the number of fines given for violating the smoking ban. The correlation between the two measures in our data was 0.83 , which is indeed substantial. This provided us with additional confidence that our measure based on SSB membership truly reflected resistance to the smoking ban.

To provide insights into the spatial distribution of resistance to the smoking ban, we mapped SSB membership as well as the number of fines per municipality (see Figures 1 and 2). This analysis revealed a high correlation between both measures of resistance, as the spatial patterns for both were very similar. Specifically, they revealed that the level of resistance was not uniformly distributed across municipalities. Moreover, the pattern of resistance did not simply reflect differences in urbanization. Even though many of the bigger cities showed high levels of resistance, a strong pocket of resistance could also be identified in the southeast of the Netherlands, which is a rather rural area. Overall, we observed that there was substantial variation in resistance to the smoking ban across communities.

Independent variables. As noted above, we gathered and combined data from many different sources to operationalize our independent and control variables. Whenever possible, we established a time lag with our dependent variable. For variables for which sufficient data were available, we even constructed different time lags. However, as community characteristics are relatively stable over time, using (different) time lags had no effect on our study's results whatsoever. A summary of the measurement and sources of each of our variables, with links to the organizations from which we obtained the data (where applicable), is provided in Table 4.

The first dimension of community cohesiveness, the level of residential stability, was measured based on (a) the number of people entering a community through residential moves relative to the number of inhabitants and (b) the number of people leaving a community through residential moves relative to the number of inhabitants. We separately calculated the share of new entrants and leavers in the community in 2007 , the year prior to the measurement of our dependent variable. We standardized the resulting variables, and, finally, inverted the variables, so that high scores on the variables reflect high levels of residential stability (Sampson, 1991: 47). Given that these two variables were highly correlated $(0.84)$, we averaged them to arrive at our final measure of residential stability. Note that only residential moves within the Netherlands are taken into account for the construction of this variable. The number of international movers (both in and out) is relatively small and almost perfectly correlated with our control variable that captures the level of population density of the community.

The second dimension of community cohesiveness, the level of kinship, was measured using information from the National Housing Survey from 2008. This survey is taken every four years, and 2008 therefore was the year closest to the measurement of our dependent variable. In this survey, a sample of 78,071 respondents designed to be representative at the municipal level was asked numerous questions regarding their living environment. Several of these questions were specifically designed to measure social cohesion (VROM, 2009), and we adopted the measure developed by Goudriaan, Wittebrood, and Nieuwbeerta (2006) based on nine of the items from this survey (see Table 4). Each item was answered on a seven-point Likert scale and our measure of kinship was based on the average answer over the nine items. The reliability of this scale is very high ( $\alpha=0.83$ in our data). To arrive at our community-level measure of kinship, we averaged the scores of all individuals in a given municipality.

The measure we used to capture the contiguity effect was calculated on the basis of our dependent variable. Using spatial econometrics, we calculated the spatially lagged variable of our dependent variable based on an exponential distance decay function (Doh \& Hahn, 2008). This variable captured the level of resistance in the communities surrounding the focal community with the weight of these neighboring municipalities exponentially diminishing with the distance from the focal municipality. Mathematically, a spatial lag takes the following form:

$$
W Y_{i}=\sum_{j=1}^{n} \frac{Y_{j}}{d_{i j}^{2}}
$$

where $W Y_{i}$ is the spatial lag of variable $Y$ for municipality $i$, and $d_{i j}$ is the geographical distance as the crow flies between the centroids of municipality $i$ 
FIGURE 1

\section{Geographical Distribution of SSB Membership}

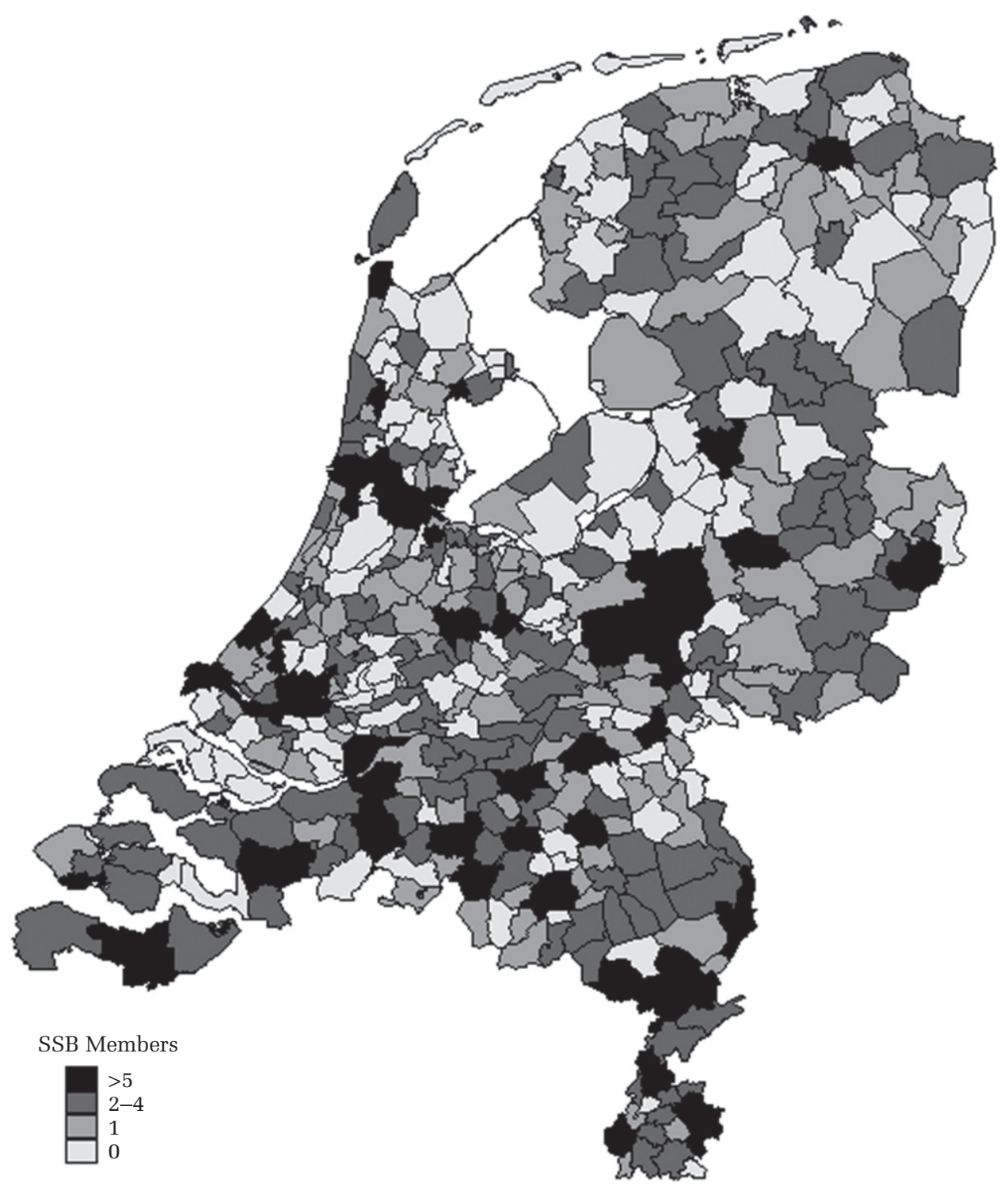

and $j$. This spatial lag is inserted in a regression equation together with a vector of other independent or control variables $\left(X_{i}\right)$, resulting in the following basic regression equation:

$$
Y_{i}=\beta_{0}+\beta_{1} X_{i}+\beta_{2} W Y_{i}+\epsilon_{i}
$$

The intuition behind a spatially lagged variable is similar to that of a time lag in, for example, panel data analysis. The only difference is that, in our case, the influence on the dependent variable did not come from the past but from the neighboring regions.

Control variables. Given that our dependent variable was the absolute number of resistors to the smoking ban, we needed to control for the size of the spawning ground from which this resistance could arise. As such, we included the number of bars and pubs in the municipality in 2008 as a control variable. To compute this control variable, we utilized information from the branch organization for hotels, restaurants, cafes, and catering.

We also controlled for the extent to which local bars might feel that their resistance was legitimized by the local government. The level of political opposition to smoking ban was measured by the percentage of voters in the municipality that voted for the only political party that opposed the smoking ban 
FIGURE 2

\section{Geographical Distribution of Fines for Violation of the Smoking Ban}

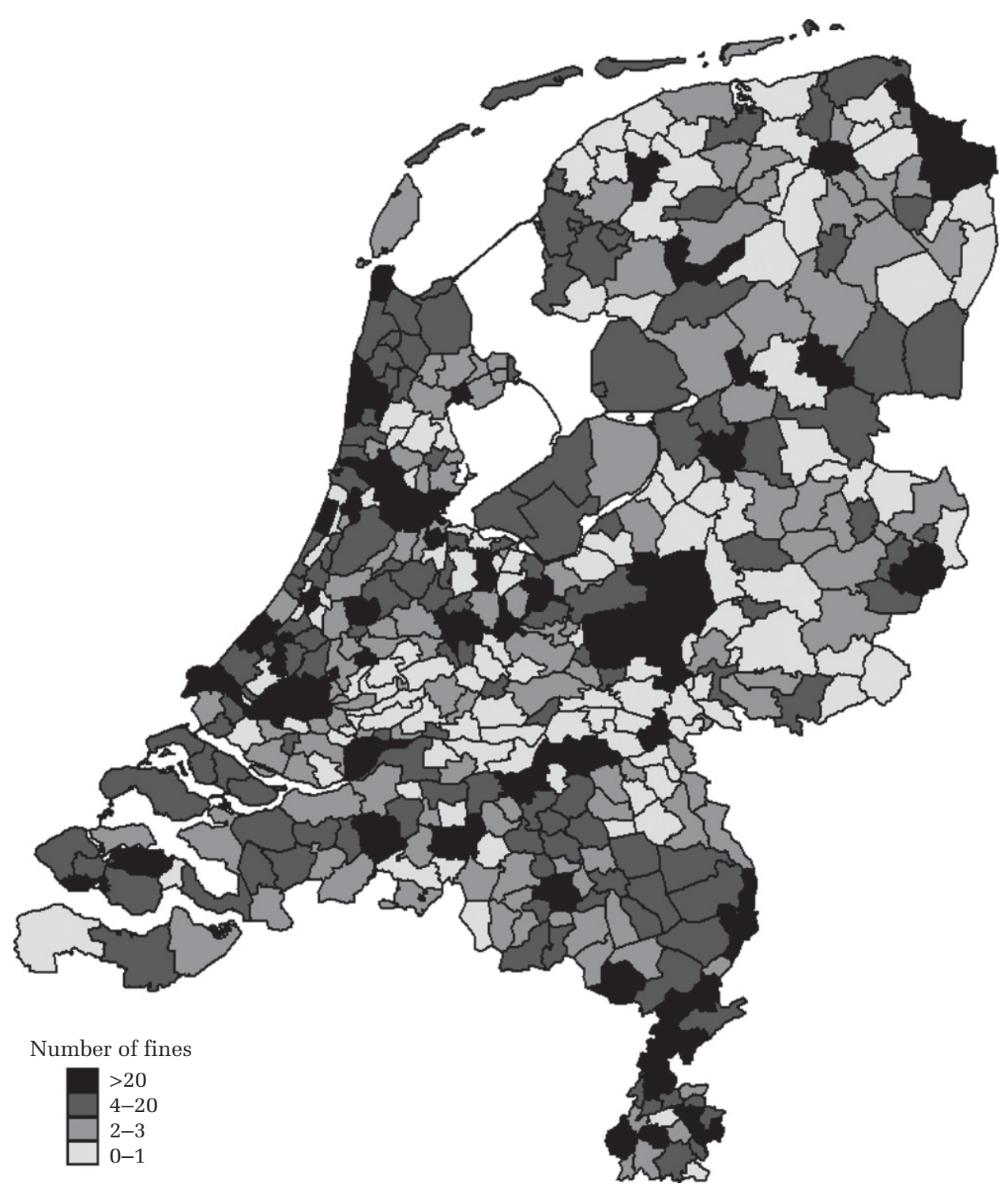

(the PVV) during the 2006 national elections. These were the last elections that took place before 2008, the year for which we measured our dependent variable. Even though the 2006 elections were national and not local, Dutch law requires people to vote in their municipality of residence. Voters can request a permit to vote in another municipality, but less than $0.1 \%$ of the voters do so. Therefore, the outcomes of the national elections also provide a very accurate reflection of the local political climate. The required information was obtained from the official records of the Dutch elections and recalculated to reflect the 2010 municipal classification.
This measure showed considerable variation, ranging between $5.7 \%$ and $38.7 \%$.

Our third control variable captured the extent to which there was local activism in favor of the smoking ban. This level of local anti-smoking activism was measured using the address information of the signees of a petition in support of the smoking ban initiative carried out in 2008, and provided to us by Clean Air Netherlands. This petition was used in the lobbying efforts to convince individual legislators and members of parliament of the support for the smoking ban among the general public, and included 54,045 signees. Many of them 
TABLE 4

Variables and Data Sources

\begin{tabular}{|c|c|}
\hline Variable & Measurement \\
\hline $\begin{array}{l}\text { Resistance to the smoking } \\
\text { ban }\end{array}$ & $\begin{array}{l}\text { Number of pubs and bars in a municipality that } \\
\text { were members of the SSB foundation in } 2008\end{array}$ \\
\hline Fines for ban violation & $\begin{array}{l}\text { Number of fines levied in 2008-2009 by the VWA } \\
\text { for violating the smoking ban }\end{array}$ \\
\hline $\begin{array}{l}\text { Community } \\
\text { cohesiveness-Residential } \\
\text { stability }\end{array}$ & $\begin{array}{l}\text { Standardized and inverted share of people leaving } \\
\text { and entering a community in } 2007\end{array}$ \\
\hline $\begin{array}{l}\text { Community } \\
\text { cohesiveness-Kinship }\end{array}$ & $\begin{array}{l}\text { Average of 7-point Likert scale answers to } 9 \text { items: } \\
\text { (1) "I feel an attachment to this neighborhood," } \\
\text { (2) "I feel at home in this neighborhood," (3) "I } \\
\text { have a lot of contact with the people who live } \\
\text { next door," (4) "I have a lot of contact with other } \\
\text { residents," (5) "I feel responsible in part for the } \\
\text { neighborhood being a pleasant place to live," (6) } \\
\text { "People are nice to each other in this } \\
\text { neighborhood," (7) "I live in a pleasant } \\
\text { neighborhood with a sense of solidarity," (8) } \\
\text { "People in this neighborhood hardly know each } \\
\text { other," and (9) "I am satisfied with the } \\
\text { composition of the population in this } \\
\text { neighborhood" }\end{array}$ \\
\hline $\begin{array}{l}\text { Community } \\
\text { contiguity-Resistance in } \\
\text { neighboring } \\
\text { municipalities }\end{array}$ & $\begin{array}{l}\text { Spatially weighted average of the percentage of } \\
\text { pubs and bars in the neighboring municipalities } \\
\text { that were members of the SSB foundation in } \\
2008\end{array}$ \\
\hline Number of pubs and bars & $\begin{array}{l}\text { Total number of pubs and bars in a municipality in } \\
2008\end{array}$ \\
\hline $\begin{array}{l}\text { Political opposition to } \\
\text { smoking ban }\end{array}$ & $\begin{array}{l}\text { Percentage of votes in the municipality for the only } \\
\text { political party (PVV) that was opposed to the } \\
\text { smoking ban during the } 2006 \text { elections }\end{array}$ \\
\hline Local anti-smoking activism & $\begin{array}{l}\text { Percentage of inhabitants of the municipality that } \\
\text { signed the petition in favor of the smoking ban in } \\
\text { bars and pubs in } 2008\end{array}$ \\
\hline
\end{tabular}

Local competition

Local demand

Population density

Socioeconomic development
Number of pubs and bars per 1,000 inhabitants in the municipality in 2008

Percentage of inhabitants ( 15 years + ) in the municipality who are both daily smokers and visit a bar or pub once a month or more (pooled data for 2007 and 2008)

Number of inhabitants in the municipality in 2008 divided by its surface area (measured in $\mathrm{km}^{2}$ )

Average gross household income (measured in thousands of Euros) in the municipality in 2008
Own computations based on the membership files of the SSB foundation aggregated to the municipal level (http://kleinehoreca.info/)

Own computations based on data disclosed by the VWA and supplied by LocalFocus (www. localfocus.nl)

Statistics Netherlands (http://statline.cbs.nl/statweb/)

Own computations based on data from the National Housing Survey (WoonOnderzoek Nederland) conducted by ABF research (http://www. abfresearch.nl) and commissioned by Statistics Netherlands

Own calculations based on the membership files of the SSB foundation aggregated to the municipal level (http://kleinehoreca.info/)

Obtained from the branch organization for hospitality and catering (www.kenniscentrumhoreca.nl)

Official records of the Dutch 2006 elections (www. verkiezingskaart.nl)

List of signees obtained from the initiator of the petition, the Clean Air Netherlands foundation (http://www.cleanairnederland.nl/). The number of signees was aggregated to the municipal level and divided by the number of inhabitants $(\times 1,000)$ of the municipality (obtained from Statistics Netherlands, http://statline.cbs.nl/statweb/)

The numbers of pubs and bars per municipality were obtained from the branch organization for hospitality and catering (www.

kenniscentrumhoreca.nl). The number of inhabitants $(\times 100)$ of the municipality was obtained from Statistics Netherlands (http:// statline.cbs.nl/statweb/)

Own computations based on data from the "continuous research on smoking habits" conducted by TNS NIPO (http://www.tns-nipo. $\mathrm{com} /$ ) and commissioned by the Dutch center of expertise for tobacco control STIVORO (http:// www.stivoro.nl/)

Statistics Netherlands (http://statline.cbs.nl/statweb/)

Statistics Netherlands (http://statline.cbs.nl/statweb/) 
$(55.4 \%)$ provided a reason for signing the petition, which allowed us to check whether these signatories really did support the smoking ban. We randomly selected $10 \%$ of all petitioners who provided a reason for signing $(2,995$ cases $)$ and checked their motives for signing the petition. While the stated reasons for signing ranged from practical or personal health reasons to ideological positions about freedom from externalities imposed by others, the vast majority (99.5\%) was indeed in favor of the smoking ban. Moreover, in order for their signature to be considered valid, signees had to list their place of residence-which could, for our purposes, be directly linked to municipalities. Our measure of local anti-smoking activism was calculated as the number of signees per municipality divided by the number of residents of that municipality (data obtained from Statistics Netherlands).

We also controlled for two economic pressures on bars within a community; namely, the level of local competition and the level of local demand from smokers. The level of local competition was measured as the number of pubs and bars in a municipality per 1,000 residents in 2008. The former information was obtained from the branch organization for hotels, restaurants, cafes, and catering (see Table 4), while the latter was obtained from Statistics Netherlands. For a few municipalities, particularly the islands in the north of the Netherlands that have high levels of tourism, this measure yielded relatively high scores. Overall, however, the measure was more or less normally distributed.

The level of local demand was measured as the percentage of residents of the municipality that were both daily smokers and visited a bar or pub at least once a month. To compute this variable, we obtained the micro data from the "continuous research on smoking habits" commissioned by STIVORO (the central coordinating organization for smoking cessation in the Netherlands) and conducted by one of the leading Dutch market research institutes (TNS NIPO). This yearly phone survey encompasses roughly 18,000 respondents. Its stratified random sampling design ensures representativeness at the municipal level if one pools at least two years of data. The research is co-funded by Statistics Netherlands and is also used to generate the official statistics regarding smoking behavior. We pooled data from the data collection waves of 2007 and 2008 and extracted the information regarding smoking behavior and bar visiting behavior. After accounting for missing data, the sample contained 33,367 valid observations. For each of these observations, we dummy coded whether the respondent was both a daily smoker and visited a bar at least once a month (score $=$ " 1 ") or not (score = "0"). Subsequently, we calculated the mean score on this dummy variable for each municipality.

We also controlled for the population density, measured as the number of people per square kilometer in the municipality, to differentiate between urban and rural areas. Note that this variable also picks up the effects of many other community-level characteristics, such as availability of cultural amenities, crime rates, health care access, and so on. These variables correlate problematically highly with each other when used simultaneously in statistical analyses. Instead of compiling a difficult-tointerpret composite index, we opted to use a single indicator that reflected the majority of these between-community differences. We used population density rather than absolute population, as there were significant variations in the surface areas of municipalities. The information necessary to compute this variable was obtained from Statistics Netherlands.

Finally, we controlled for the level of socioeconomic development in the municipality, measured as the average household income in the community. Again, this variable picks up almost all variation between communities relating to socioeconomic features such as education levels, unemployment rates, real estate prices, and so on. Instead of compiling a difficult-to-interpret composite index, we opted to use a single indicator that reflected the majority of these between-community differences. The information required to calculate this variable was obtained from Statistics Netherlands, which computes it as the total gross income in a region divided by the number of households in the region.

\section{Statistical Analyses}

We used a negative binomial regression model to estimate the effects of our independent variables on the level of resistance to the smoking ban. Note that, due to the inclusion of the spatial lag of the dependent variable in our models, econometrically, our models are negative binomial spatial-lag models (Doh \& Hahn, 2008). The choice of this model was governed by the distribution of the dependent variable, which is a count variable with a highly non-normal distribution that rules out conventional ordinary least squares (OLS) regression models (Verbeek, 2004). For count data, the family of Poisson regression models is most applicable (Long, 1997), but, given that our 
dependent variable is also characterized by overdispersion (variance $=17.56$; mean $=2.45$ ), which is problematic for the regular Poisson model (Hilbe, 2007), the negative binomial model was the most suitable type of statistical analysis. We estimated all models using robust standard errors.

Before estimating our models, we log-transformed all independent and control variables. We did so for two reasons. First, all variables exhibited a significant degree of skewness, which is reduced by log-transformation. Second, log-transforming these variables has the advantage that the regression coefficients can be interpreted as elasticities (Hilbe, 2007). However, an important characteristic of the negative binomial model is that it has a multiplicative rather than an additive model specification (Hilbe, 2007), implying that the impact of a change in an independent variable on the dependent variable depends on the values on all other independent variables. In order to provide insights into the magnitude of the effects of our independent variables, we conducted marginal effects analyses. The effects that we report reflect the average elasticity of the independent variable across all observed values for the other variables in the model (Hoetker, 2007).

\section{RESULTS}

The descriptive statistics and pairwise correlations between all of the variables, including the control variables, are presented in Table 5. Several interesting results stand out. First, more than $12 \%$ of the bars were members of the SSB, which is quite a substantial proportion. Second, as expected, there is a moderately strong correlation between the number of pubs and bars in a region and the resistance to the smoking ban (0.68). This correlation underlines the need to include the potential number of resistors as a control variable. Besides this correlation, however, all correlations are of modest size, indicating that there are no multicollinearity problems in the data. Third and finally, there is a positive but relatively low (0.26) correlation between our two dimensions of social cohesion. This substantiates our arguments that these are two distinct dimensions of social cohesion. Moreover, this low correlation is in line with earlier empirical work that examined the relation between these two community characteristics and found no relation between the two after controlling for other community characteristics (Tolsma et al., 2009).

We estimated negative binomial models to test our hypotheses. Model 1 is the baseline model, in which

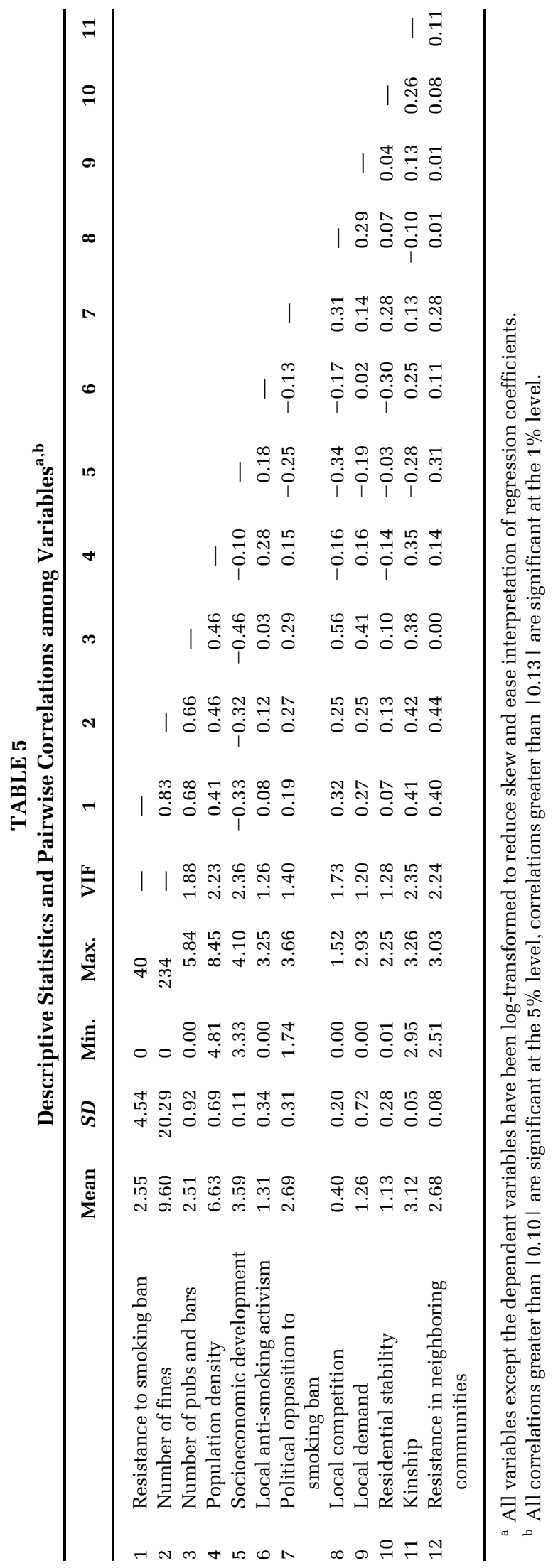


only the control variables are included, and serves to evaluate the added explanatory value of the independent variables. Model 2 adds the three direct effects of the independent variables, and serves to test Hypotheses 1-3. Models 3 and 4 test the interaction effects between each of the two dimensions of community cohesiveness and the level of resistance in neighboring municipalities. Model 5, finally, simultaneously tests both interaction effects. The results of these models are reported in Table 6 .

Table 6 reveals that all models are highly significant and that all exhibit a better model fit (significantly lower log-likelihoods) than the baseline model. Furthermore, the $\alpha$ parameter, which corrects for the overdispersion of the dependent variable, is highly significant in all models, indicating that the negative binomial model was indeed the appropriate estimation technique.

Model 1 shows that most control variables have significant effects on the level of resistance, the only exception being the level of socioeconomic development. As expected, the number of pubs and bars in a region has a strong positive effect on the level of resistance. This effect suggests that the larger the pool of potential resistors, the higher the level of resistance. More specifically, an increase in the number of bars in a community by $1 \%$ increases the level of resistance by $0.274 \%$.

Moreover, the higher the share of voters for the PVV in a municipality, the higher the level of resistance to the smoking ban. The effect size reported in Table 6 implies that an increase in the share of PVV voters in a municipality by $1 \%$ corresponds to an increase of the resistance to the smoking ban by $0.435 \%$. Moreover, we found that the higher the population density in the community, the higher the level of resistance (elasticity of 0.509).

The results show, too, that the higher the level of anti-smoking activism in a municipality, the lower will be the resistance to the smoking ban: an increase of $1 \%$ in the share of the population in a community that signed the petition in favor of the smoking ban is associated with, on average, $0.309 \%$ less resistance to the smoking ban in the community.

Both the level of competition bars face and the level of demand originating from smokers have a positive association with the level of resistance to the smoking ban in a community. With regard to the level of competition, we found that an increase of the level of competition of $1 \%$ is related to an increase in the resistance in the community of $1.129 \%$, and an increase in the share of demand that originates from smokers by $1 \%$ is associated with $0.120 \%$ more resistance among bars in the community.

Model 2 shows that an increase in community residential stability of $1 \%$ corresponds to an increase in resistance to the smoking ban of $0.484 \%$, thereby confirming Hypothesis 1. For the degree of kinship in a community, we also found a statistically significant positive effect on the level of resistance to the smoking ban. In this case, an increase of 1\% in the level of kinship is associated with an increase in resistance to the smoking ban of $1.901 \%$, thereby confirming Hypothesis 2. Finally, Model 2 also provides strong support for Hypothesis 3: an increase in the level of resistance in neighboring communities of $1 \%$ relates to a $0.520 \%$ increase in resistance to the smoking ban.

The findings reported in Models 3-5 demonstrate that the contiguity effect of resistance to the smoking ban becomes stronger as community cohesiveness, both in terms of residential stability and kinship, decreases. We found this both in the partial models (Models 3 and 4) as well as in the full model (Model 5), providing strong support for Hypotheses 4 and 5. To make these interaction effects easier to interpret, we estimated and plotted the level of resistance to the smoking ban for all combinations of community cohesiveness and levels of resistance in neighboring communities. Moreover, as point significance does not imply significance over the whole range of the variables in non-linear models (Hoetker, 2007), we also created two plots in which the effect, including the $95 \%$ confidence interval, of resistance in neighboring communities is depicted for two different levels of residential stability and kinship.

The results, as shown in Figures 3 and 5, clearly demonstrate that, as predicted in Hypotheses 4 and 5 , the effect of resistance in neighboring communities is much weaker for more cohesive communities. Moreover, Figures 4 and 6 also indicate that, for the largest part of the range of resistance in neighboring communities, the predicted level of resistance is significantly different for different values of kinship/residential stability.

Note that Figures 3 and 5 also show that, when the level of resistance to the smoking ban in neighboring communities is low, a decrease in the focal community's cohesiveness lowers the level of resistance in it. In other words, low levels of cohesiveness make a community more susceptible and its boundaries more permeable to ideas and opinions from neighboring communities, regardless of whether these are in favor of or against the smoking ban. This finding is remarkably similar for both dimensions of community cohesiveness in our study.

\section{Robustness Checks}

We performed several robustness checks to assess the sensitivity of our findings to changes in variable 
TABLE 6

Negative Binomial Regression Models of Resistance to the Smoking Ban ${ }^{\text {a,b }}$

\begin{tabular}{|c|c|c|c|c|c|c|c|c|c|c|}
\hline & \multicolumn{2}{|c|}{ Model 1} & \multicolumn{2}{|c|}{ Model 2} & \multicolumn{2}{|c|}{ Model 3} & \multicolumn{2}{|c|}{ Model 4} & \multicolumn{2}{|c|}{ Model 5} \\
\hline & $\boldsymbol{B}$ & $S E$ & $\boldsymbol{B}$ & $S E$ & $\boldsymbol{B}$ & $S E$ & $\boldsymbol{B}$ & $S E$ & $\boldsymbol{B}$ & $S E$ \\
\hline \multicolumn{11}{|l|}{ Control variables } \\
\hline $\begin{array}{l}\text { Number of pubs } \\
\text { and bars }\end{array}$ & $0.274^{* *}$ & 0.073 & $0.256 * *$ & 0.09 & $0.271 * *$ & 0.097 & $0.284^{* *}$ & 0.081 & $0.280 * *$ & 0.081 \\
\hline $\begin{array}{l}\text { Population } \\
\text { density }\end{array}$ & $0.509 * *$ & 0.087 & $0.445^{* *}$ & 0.146 & $0.471 * *$ & 0.133 & $0.446 * *$ & 0.088 & $0.405^{* *}$ & 0.095 \\
\hline $\begin{array}{r}\text { Socioeconomic } \\
\text { development }\end{array}$ & -0.663 & 0.933 & -0.895 & 0.806 & $-1.448^{*}$ & 0.636 & -1.185 & 0.889 & $-1.665^{*}$ & 0.781 \\
\hline $\begin{array}{l}\text { Local anti- } \\
\text { smoking } \\
\text { activism }\end{array}$ & $-0.309^{*}$ & 0.144 & $-0.246^{\dagger}$ & 0.139 & $-0.224^{\dagger}$ & 0.118 & $-0.336^{*}$ & 0.160 & $-0.262^{\dagger}$ & 0.158 \\
\hline $\begin{array}{l}\text { Political } \\
\text { opposition to } \\
\text { smoking ban }\end{array}$ & $0.354^{\dagger}$ & 0.194 & 0.203 & 0.247 & 0.196 & 0.232 & 0.222 & 0.183 & 0.094 & 0.201 \\
\hline Local competition & $1.290^{*}$ & 0.567 & $1.467 * *$ & 0.521 & $1.432^{* *}$ & 0.535 & $1.411^{* *}$ & 0.532 & $1.527 * *$ & 0.498 \\
\hline $\begin{array}{l}\text { Local demand } \\
\text { Independent } \\
\text { variables }\end{array}$ & $0.120^{* *}$ & 0.046 & $0.117^{*}$ & 0.051 & $0.109^{*}$ & 0.045 & $0.136^{*}$ & 0.054 & $0.111^{*}$ & 0.048 \\
\hline $\begin{array}{l}\text { Residential } \\
\text { stability }\end{array}$ & & & $0.484^{*}$ & 0.231 & $1.096 *$ & 0.485 & & & $1.511 * *$ & 0.551 \\
\hline Kinship & & & $1.901 *$ & 0.915 & & & $0.620 * *$ & 0.135 & $0.657 * *$ & 0.173 \\
\hline $\begin{array}{l}\text { Resistance in } \\
\text { neighboring } \\
\text { communities }\end{array}$ & & & $0.520^{*}$ & 0.231 & $1.409 * *$ & 0.471 & $0.591^{* *}$ & 0.138 & $0.787 * *$ & 0.203 \\
\hline $\begin{array}{l}\text { Resistance in } \\
\text { neighboring } \\
\text { communities } \times \\
\text { Residential } \\
\text { stability }\end{array}$ & & & & & $-0.962^{*}$ & 0.434 & & & $-1.345^{* *}$ & 0.504 \\
\hline $\begin{array}{l}\text { Resistance in } \\
\text { neighboring } \\
\text { communities } \times \\
\text { Kinship }\end{array}$ & & & & & & & $-0.245^{* *}$ & 0.057 & $-0.258^{* *}$ & 0.073 \\
\hline $\begin{array}{l}\text { Model } \\
\quad \text { information }\end{array}$ & & & & & & & & & & \\
\hline$N$ & 427 & & 427 & & 427 & & 427 & & 427 & \\
\hline $\begin{array}{l}\text { Model } \\
\text { significance }\end{array}$ & 0.000 & & 0.000 & & 0.000 & & 0.000 & & 0.000 & \\
\hline$\alpha$ & $0.260 * *$ & & $0.245^{* *}$ & & $0.252^{* *}$ & & $0.239 * *$ & & $0.228 * *$ & \\
\hline Log-likelihood & -722.41 & & -718.24 & & -717.68 & & -716.36 & & -711.17 & \\
\hline $\begin{array}{l}\chi^{2} \Delta \text { Log- } \\
\text { likelihood with } \\
\text { Model } 1\end{array}$ & - & & $8.39 *$ & & $9.45^{*}$ & & $12.08 * *$ & & $22.47 * *$ & \\
\hline
\end{tabular}

a All reported standard errors are robust clustered standard errors at the provincial level.

${ }^{\mathrm{b}}$ Reported coefficients reflect the average elasticity of the independent variable across all observed values for the other variables in the model.

${ }^{+} p<.10$
${ }_{*} p<.05$
${ }^{*} p<.01$

specification and estimation methods. The results of these robustness checks are reported in Table 7.

First, we estimated our full model excluding the municipalities that did not have at least one bar (four cases), based on the notion that, in such municipalities, resistance cannot occur, given our measure of it. The results of this analysis, reported in Table 7, Model 6, yielded results nearly identical to those reported in Table 6 , indicating that our results are not sensitive to this change. 
FIGURE 3

\section{Interaction Effect of Residential Stability and Resistance in Neighboring Communities}

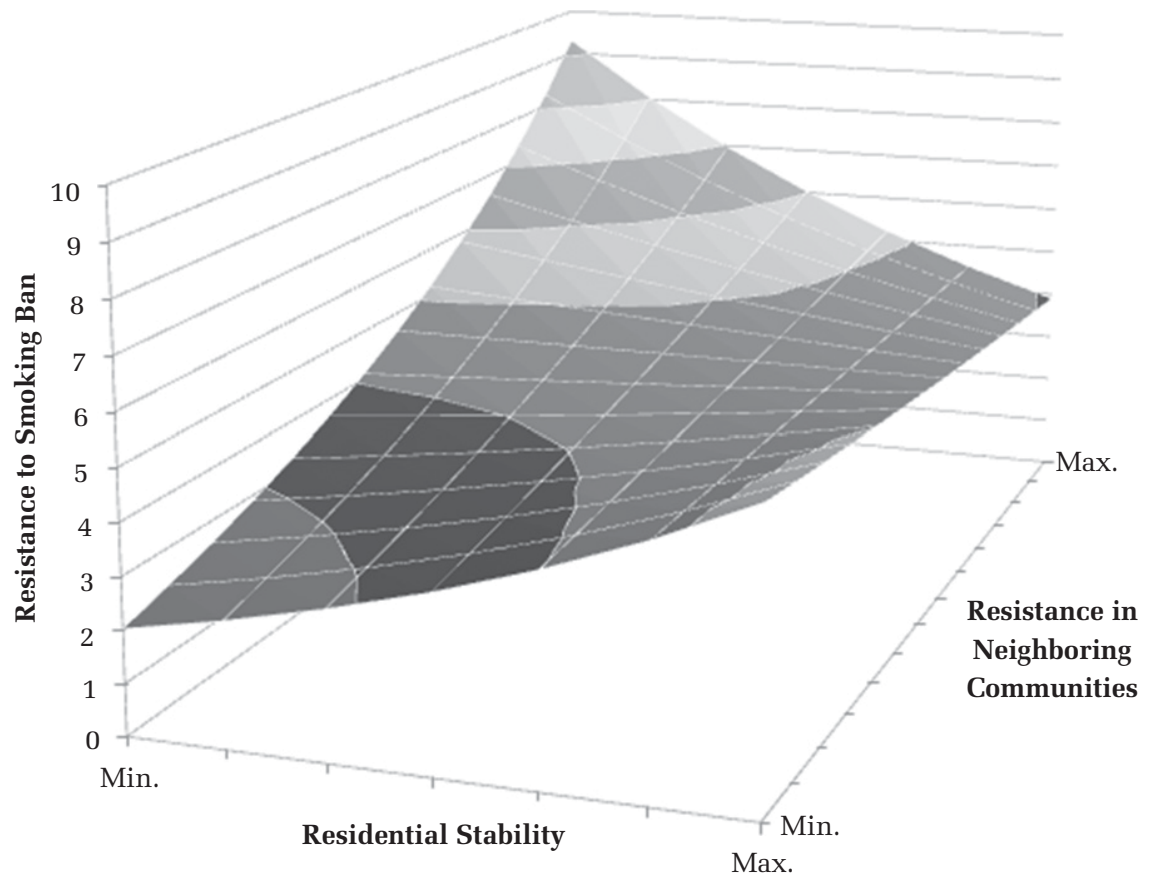

Second, we ran our analyses with a different specification of the dependent variable. Instead of using the absolute number of resistors, we calculated the share of bars in the municipality that resisted by dividing the number of resistors by the total number of bars in the municipality. The resulting variable was highly skewed, so we log-transformed it and performed an OLS regression with the same list of independent and control variables. Again, doing so yielded substantively identical results to those reported in Table 6 (see Table 7, Model 7).

Third, we checked whether our analyses were not simply picking up whether there is resistance in a region instead of the magnitude of resistance. To assess this possibility, we excluded all cases in which there was no resistance (126 cases) and re-ran our negative binomial models (see Table 7, Model 8). Again, the results obtained were similar to those reported in Table 6. All the coefficients had the same sign, but some of the significance levels did change somewhat due to the large drop in the number of observations.

Fourth, we ran our full model with the number of fines given for violating the smoking ban as the dependent variable (Table 7, Model 9). Again, the results are greatly similar to those reported in Table 6 . There are, however, two exceptions to this similarity, which strengthen our confidence in the validity of our dependent variable. These exception are the positive effect of the level of anti-smoking activism (negative in all other models) and the negative effect of the level of political opposition to the smoking ban (positive in all other models). These exceptions are very logical, based on the process of how bars were selected for inspection by the VWA. Being understaffed, the VWA largely relied on tips from patrons to inspect bars violating the smoking ban. So, the number of inspections and fines in a municipality would depend on, among other things, the willingness of bar patrons to snitch to the VWA. Antismoking activists are probably more likely to do this, whereas voters for the only political party against the smoking ban are less likely to do so.

Fifth, we checked whether our results would still apply with a different specification of the spatial lag variable. Instead of using a quadratic distance decay function to calculate the spatial lag, we use a contiguity-based measure in which only the scores of directly neighboring regions were taken into account in the spatial lag measure. Model 10 of Table 7 reveals that doing so yields once more greatly similar results to those reported in Model 5 (Table 6).

Finally, we re-estimated our full model with a control for population size instead of population 
FIGURE 4

The Effect of Resistance in Neighboring Communities for Two Levels of Residential Stability

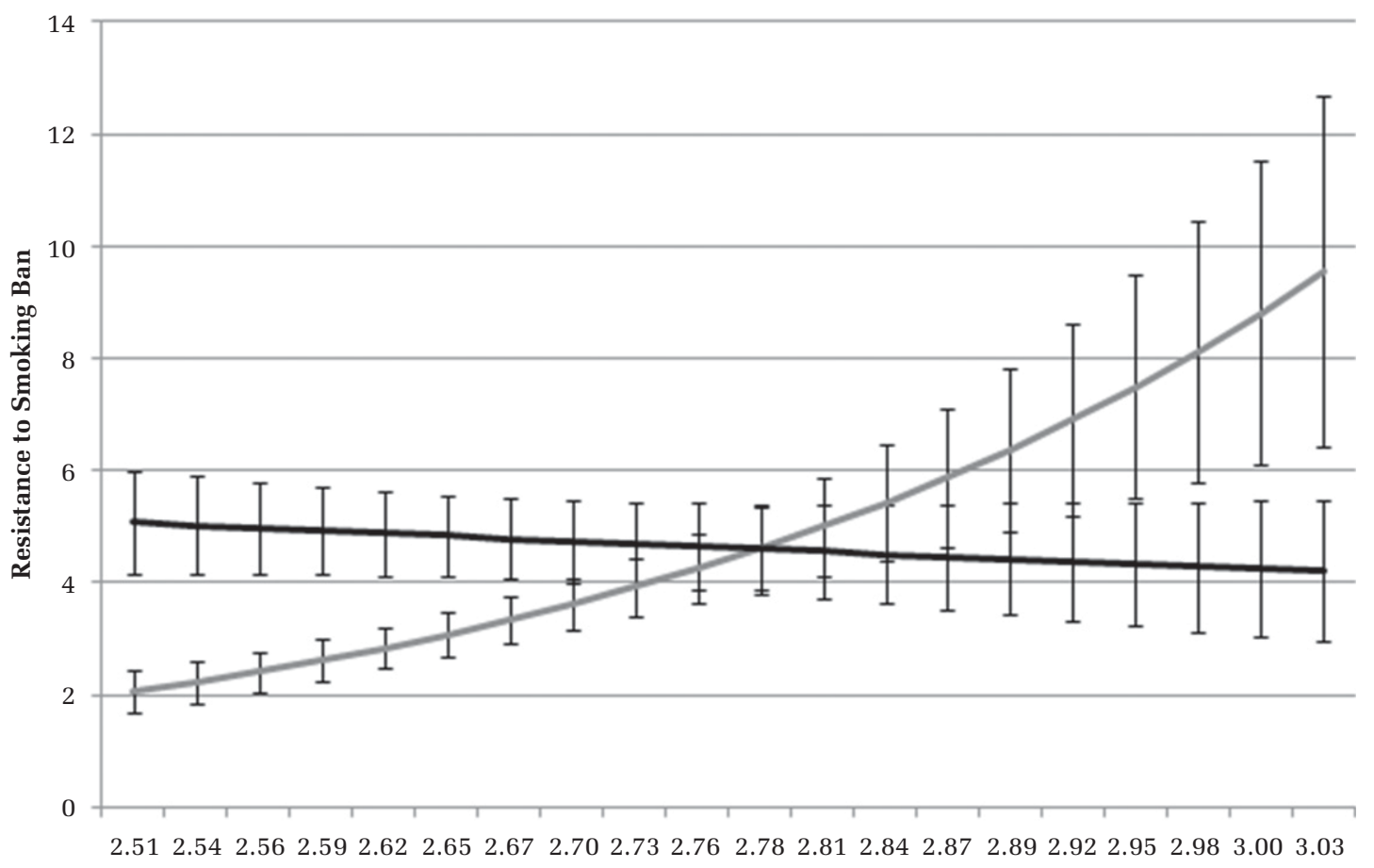

Resistance in Neighboring Communities

5th percentile Residential Stability

density. In principal, population size and population density are not necessarily related to each other. Even though, in the context of Dutch communities, they correlate with 0.73 , we performed this robustness test to rule out the possibility that the specification of this control variable influenced our results. Model 11 in Table 7 reveals that this was not the case.

Overall, we find that our results are highly robust to changes in the model specification as well as changes in the specification of key variables in the model.

\section{DISCUSSION}

Small bars embedded in communities that exhibit greater residential stability and kinship, together constituting a higher level of community cohesion, resisted institutional pressure from the state more than their counterparts located in less cohesive communities. This finding incorporates three components-small organizations, community cohesion, and a powerful adversary - that together point toward the key discovery of this study. It was indeed the interrelation among the bars and their cohesive, supportive community that provided the foundation for these powerless organizations to resist state regulations. With the enforcement of strong institutional pressures that are seen as harmful to members of a community, the social cohesion of a community might be even further increased (e.g., Sampson, 1991) and offer relatively powerless actors strong arms with which to oppose a regulatory force. In this section, we discuss, first, how we see this study in the context of research on institutional processes in and across communities, followed by the novelty and significance of our David-versusGoliath scenario and findings, and conclude with some observations concerning resistance exhibited in the specific context of smoking and smoking control.

Communities are important social arenas for institutional processes, yet they have attracted scarce theoretical and empirical attention (Marquis et al., 2007). They are meaningful in that they are assumed to be relatively homogeneous with respect to a variety of economic, social, and cultural characteristics, and are more likely to share prospects and fates as compared to society as a whole (e.g., Brint, 2001). 
FIGURE 5

Interaction Effect of Kinship and Resistance in Neighboring Communities

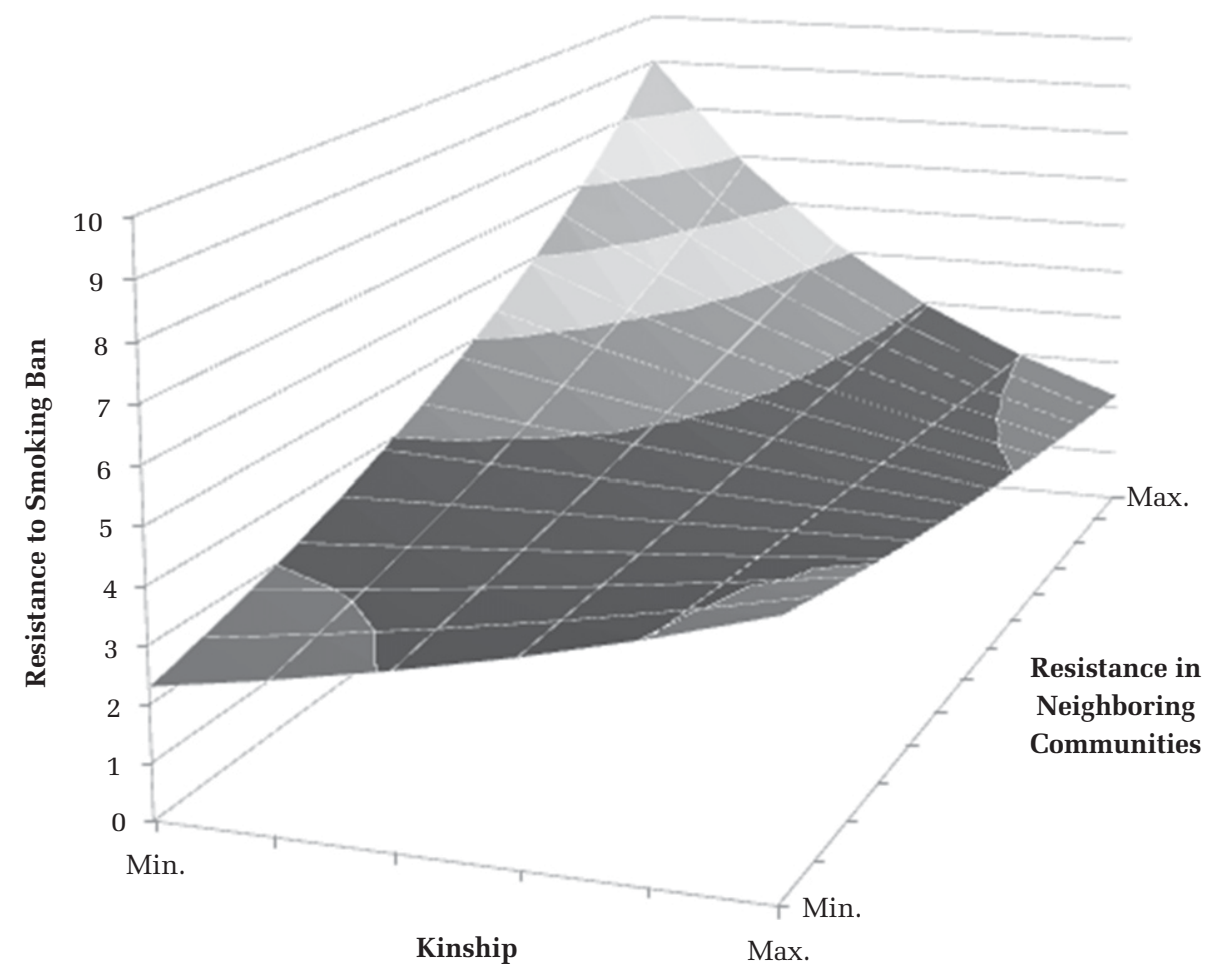

Significant processes of conformity and contention over actions, regulations, and norms take place at the community level, but to date have received insufficient attention from institutional scholars. This paper addresses such processes in Dutch communities (municipalities), and finds support for the notion that communities' distinctive local endowments, as expressed in their social cohesion, matter and influence local organizations' actions above and beyond a multitude of other factors. In particular, the present research focuses on organizations' resistance to a regulative change as exemplified by bars' opposition to, and active defiance of, a complete ban on smoking on their premises that was imposed by the Dutch government. The criticality of local protest and activism was demonstrated in Ingram, Yue, and Rao's (2010) study, but their focus was different from ours. Their study established the importance of local sources of resistance to a change that would affect the community (the proposed establishment of a Wal-Mart store), whereas we focus on the struggle between the state and small businesses as they occur within the boundaries of distinct local social entities. Our contribution is thus "bringing the community [back] in" to the discussion and analyses of institutional processes, in particular when contestation is involved. Regardless of whether the institutional pressure originates from the state or other actors, we theorize and show that the heterogeneous responses of organizations to such pressures originates from their embeddedness, in particular, and different local social settings. As Ingram et al. (2010: 84) asserted, "protests are not distributed randomly across communities," and we show empirically that the degree of a community's cohesiveness varies as do other community attributes, and claim that the level of resistance from small powerless organizations is determined by that - that is, the community's overall social endowment as well as its specific local economic features. As such, we suggest that resistance is not a "narrow strategic response" (Marquis \& Lounsbury, 2007: 815), but should be understood instead as being actively shaped by and embedded in social structures.

In our case, the social structures are local communities that facilitate, support, and even stimulate the resistance by small bar owners against a powerful actor. We demonstrated that community cohesion is a multidimensional construct that consists of the residential stability, fostering a latent relational 


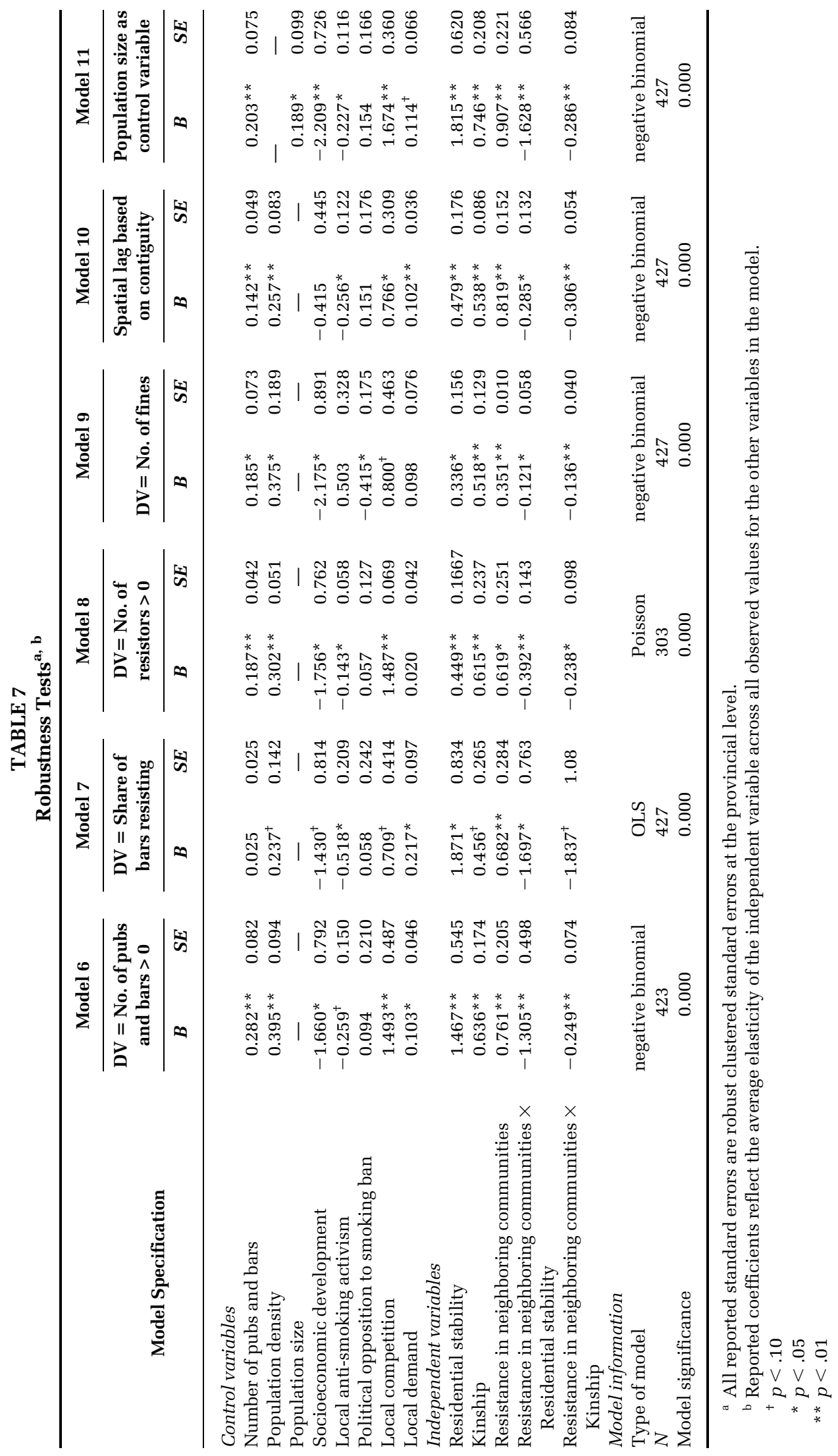


FIGURE 6

The Effect of Resistance in Neighboring Communities for Two Levels of Kinship

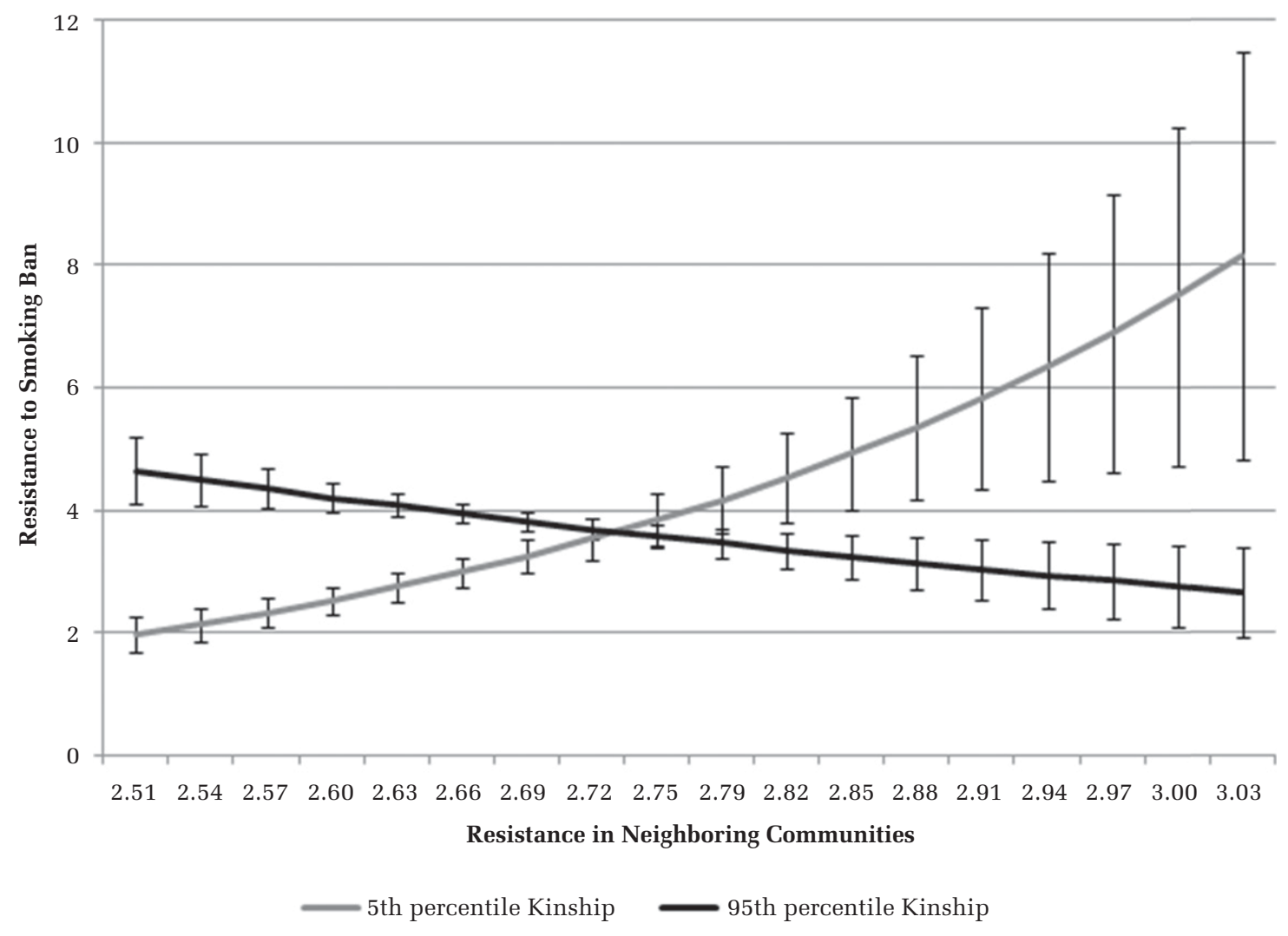

infrastructure in the community, and kinship, which generates a sense of belonging and care for the community. A highly cohesive community has more impervious boundaries that are less open or receptive to external information, ideas, and values. It is important to reiterate that we distinguished between the "physical permeability" of a community boundary, which means that the likelihood of ideas being "physically carried in" is reduced due to less movement of residents across shared boundaries, and the "cognitive permeability" of a community boundary, which refers to the strong sense of belonging to a particular community and the accompanying normative framework that limits the utilization of ideas, norms, and values from beyond the community's boundary. Whereas institutional scholars have predominantly investigated the ideational or symbolic aspects of institutional pressures (see Jones, Boxenbaum, \& Anthony, 2013; Lepoutre \& Valente, 2012), our study shows that structural features, herein represented by the social boundary of a community, are equally important in understanding responses to institutional pressures.
Moreover, a focus on the geography of institutional resistance stems from a model that depicts the community as a meaningful level of analysis. If communities vary with respect to the level of resistance to institutional pressures, while, at the same time, these communities are embedded in a larger social context, and are thus affected by it, then both concepts should be taken into account, as we have done here, when studying both resistance and mimetic behavior. Adding the specific geographical consideration requires scholars to better identify the underlying reasons for resistance before arguing for and empirically testing institutional processes. The value of combining the spatial approach with a community's social characteristics is further demonstrated by the results of the interaction terms in our study that showed the contiguity effects of resistance from neighboring communities diminishing when the focal community was more cohesive, for both dimensions of cohesion.

It is common in analyses of institutionalization processes to focus on "successful" institutionalizations, especially so when the source of the pressure is 
the state (see Dobbin \& Sutton, 1998; Tolbert \& Zucker, 1983). In the Netherlands, the debate over the anti-smoking ban as it applied to bars continued to evolve even after the legislation took effect in July 2008. Contestation over the regulation involved not only parliamentary debates and animated media coverage but moved into the courts as well. In February 2009, owners of the Café de Kachel in Groningen (in the north of the Netherlands) were the first individuals found guilty of repeated violations of the anti-smoking ban in a criminal court, and the bar was ordered to close for one month. The criminal prosecution of other bar owners followed. With financial support from the SSB, however, the owners of Café de Kachel and several other bars appealed their sentences (Gonzalez \& Glantz, 2011: 10). Because of the ongoing litigation, the Minister of Health was asked by other members of parliament to exempt owner-run venues, and, in 2009, enforcement by the VWA was suspended in owner-run bars without employees (Gonzalez \& Glantz, 2011). In May 2009, a Dutch appeals court ruled that small bars with no staff except their owners were exempt from the ban, as the Dutch ban had been based on the right of employees to work in a smoke-free environment. On February 23, 2010, though, the Supreme Court overturned the lower court's appeal and ruled that there will be no exceptions to the smoking ban; approximately 10,000 establishments were directly affected and had to implement the smoking ban in full. However, the new government that was formed after the 2010 elections agreed to exempt small bars. Consequently, on November 2, 2010, the new Minister of Health, Edith Schippers, announced that she would no longer enforce the smoking ban for small bars (under $70 \mathrm{~m}^{2}$ ) without staff. A 2012 study from the VWA concluded that, in $80 \%$ of these small bars, customers were smoking again (VWA, 2012).

Hence, this study illustrates a case in which the state was unsuccessful in imposing regulations on small business organizations. The role of government and the impact of its policies have been frequently studied (e.g., Carroll, Goodstein, \& Gyenes, 1988; Dobbin \& Dowd, 1997), but the complexity of its interaction with various affected parties has been underestimated. Vermeulen, Büch, and Greenwood (2007) demonstrated the failure of the Dutch government to create a market in the concrete industry, but, in their case, the government used voluntary agreements and the actors involved were large firms. Other studies have shown that corporate actors prove far from powerless in the face of regulatory forces (e.g., Deephouse, 1999; Schneiberg \& Bartley,
2001) and are capable of active resistance by establishing a broad coalition of established players in the field. Our example is especially noteworthy, given that the organizations in question are not giant businesses with very deep pockets and throngs of lobbyists but small bars, owner-run establishments. As described above, they were able to challenge the regulations and prevailed. This outcome provides additional support to the idea that social context matters, and that when an organization, however small, serves an important social function in its community and joins forces with other, similar organizations in its immediate environment, it can exert power and influence above and beyond its net economic contribution and/or value, even in the face of strong institutional pressures.

Moreover, considering the nature of the actors and their relative position in an institutional field, this study's context and ultimately its results provide a compelling "mirror image" to Durand and Jourdan's (2012) study focusing on alternative conformity. It reflects the role of "secondary" resource providers (minority logic holders) in inducing alternative conformity among organizations, thus highlighting the possibility that, in addition to organizations' adherence to pressures emanating from primary resource providers, the effect of the peripheral sources of pressures in an industry, which, over time, may also contribute to a change in the "rules of the game," shouldn't be neglected. In our study, we focus on organizations (not pressureproducing actors) that are small and arguably peripheral in the overall industry (hospitality), and on (ultimately successful) resistance (not conformity) to a powerful actor-the state. Taken together, these two studies highlight the crucial role of the more marginal actors (source of pressure or recipient) in affecting institutional change over time. This area has not received sufficient attention to date, and opens up new opportunities to provide theoretical nuance and precision in the study of institutional dynamics.

The points discussed above are even more significant given the issue that is being contested. The harmful consequences of tobacco use and of exposure to tobacco smoke are scientifically well founded, and have been so for some time. Consequently, the various policies and measures taken since the 1970s to eliminate those effects, certainly in the developed countries, are also widespread and taken as noncontroversial-in short, they are seen as institutionalized. The findings of our study tell us something about how some issues might possibly not 
be institutionalized even if on the face of it they are. This may indicate that, in the conceptualization and empirical investigation of institutionalization as a process as well as of its outcomes, we should dig deeper to discover undercurrents that continue to churn and trigger resistance to a given regulation, norm, or social expectation. A confluence of interests and beliefs, as expressed by a variety of actors such as businesses, politicians, NGOs, the media, and individuals, together contributing to a heightened institutional complexity can possibly undermine even what on the surface seems like highly institutionalized regulations or sets of practices.

A unique feature of the present study is that we could directly measure its central concept, resistance to change, which is rarely done in institutional studies on resistance (Marquis \& Lounsbury, 2007). The resisting organizations took an active step, joined the SSB group (which costs 250 Euros), and openly defied the smoking ban ("You probably have already heard about the lawsuit against us. We ask all of you to support us in any way you can, so we will not bear the brunt of this ridiculous policy of our Minister. We will fight it until the bitter end"; owners of the Café de Kachel on their blog). The use of such direct measures increases the external validity of our findings and our confidence in the relationships that became evident in the analyses. It is also instructive to highlight the control variables, which, while their specific effects were not hypothesized, nonetheless provide additional evidence of the importance of the community as a level of analysis-communities vary on multiple dimensions, even beyond the predictable economic variation. Additionally, all control variables' effects were in the expected direction, as explained in the results section, supporting the significance of a community's social cohesion when theorizing about organization resistance. That is, the community cohesion's effect holds even when intracommunity attitudes varied with respect to smoking bans, thus providing an indication of a hierarchy of values; when one central value shared by most is threatened, other values, which may exhibit a higher level of disparity, become secondary to the issue at hand.

While this study has a number of important strengths, there are some boundary conditions to review. First, our theory predominantly applies to organizations that are small and relatively powerless actors. Larger and more powerful organizations probably have a different range of responses at their disposal and may be less dependent on their community for support. Second, in our study, the institutional pressure came from a powerful and highly legitimate actor, the Dutch national government. If the pressure were to stem from weaker and less legitimate actors, resistance may be less risky, which, in turn, is likely to alter the role of community endowments in the rise of resistance. Third, our theoretical arguments are applicable to situations in which institutional pressures threaten the normative framework of the community; however, in cases in which institutional pressures do not directly threaten the normative framework of a community, it is unlikely that weak actors, such as small bars, could rally enough support to successfully resist the pressure.

Another boundary condition of our work pertains to the level of traction on the causal mechanisms at work. The time lag in our data structure, the temporal stability of the community characteristics, and the supportive qualitative evidence make reverse causality rather implausible. Nonetheless, future work could benefit from obtaining and analyzing data over longer periods of the dynamics of organizations' resistance to regulatory pressures at the community level. Data availability and the turn of events (i.e., the success of the small bars' resistance) prevented us from having access to such data. It would be interesting and informative, however, to document how the positions and achievements of contesting parties change over time, and whether different community characteristics matter more or less at different points in time. Additionally, having more fine-grained measures of local social endowments could help in further disentangling the various drivers of community-level resistance. An example, related to the dynamic aspect mentioned above, would be to include the history of community activism. A community with a rich, spirited history of involvement in protests or campaigns on issues relating to local concerns may be better positioned to face any new challenges that require mobilization; in other words, it has built a community activism endowment over time. This would also be a way to ameliorate a remaining causality problem in our study, that of simultaneity. There might be a (historically developed) common factor that influences both the level of social cohesion and the level of resistance in a community. We tried to rule out such common factors by controlling for many other community characteristics, but cannot rule out that there may be community characteristics, (specifically, historically determined intangible factors) that we may have omitted. If information on the 
development of activism endowment and the type of issues that were addressed could be obtained, then it should become possible to determine whether this endowment is general in nature (i.e., the more involvement in past protestation, the more likely future activity will be) or if future involvement is issue specific (i.e., there needs to be some affinity between past and future issues in order to trigger involvement). An examination of these questions could address the uncertainties concerning communities' capacity to organize and how this might alter the interactions between communities and organizations functioning and residing in them.

Future research could also look at other types of communities, such as virtual or open-source communities, that also exhibit a collective sense of "weness" (Dahlander \& Magnusson, 2005). These are normally well-organized communities with established communication channels, and, in a prior study on open-source software communities (Linux user groups), the importance of ideology and shared values, rituals, and traditions was demonstrated (Bagozzi \& Dholakia, 2006). Such groups are often also small and powerless communities that may have to stand up to large corporations (our "David vs. Goliath" scenario), and so the present study's results may be generalizable to various such communities assuming that they share some of the features we found to be significant. Finally, from a practical perspective, our study's findings suggest that it is advisable for managers to be familiar with the characteristics of the community in which their organizations operate, as community characteristics in general, and cohesion in particular, may have a substantial impact on organizations' activities and fates.

\section{REFERENCES}

Almandoz, J. 2012. Arriving at the starting line: The impact of community and financial logics on new banking ventures. Academy of Management Journal, 55: 1381-1406.

Bagozzi, R. P., \& Dholakia, U. M. 2006. Open source software user communities: A study of participation in Linux user groups. Management Science, 52: 1099-1115.

Bielefeld, W., \& Corbin, J. J. 1996. The institutionalization of nonprofit human service delivery: The role of political culture. Administration \& Society, 28: 362-389.

Boschma, R. 2005. Proximity and innovation: A critical assessment. Regional Studies, 39: 61-74.

Bowles, S., \& Gintis, H. 2002. Social capital and community governance. The Economic Journal, 112: F419-F436.
Brint, S. 2001. Gemeinschaft revisited: A critique and reconstruction of the community concept. Sociological Theory, 19: 1-23.

Carroll, G., Goodstein, J., \& Gyenes, A. 1988. Organizations and the state: Effects of the institutional environment on agricultural cooperatives in Hungary. Administrative Science Quarterly, 33: 233-256.

Carroll, G. R., \& Wade, J. 1991. Density dependence in the organizational evolution of the American brewing industry across different levels of analysis. Social Science Research, 20: 271-302.

Castells, M. 1997. The information age, vol. 2: Economy, society and culture-the power of identity. Oxford, England: Blackwell.

Chan, J., To, H.-P., \& Chan, E. 2006. Reconsidering social cohesion: Developing a definition and analytical framework for empirical research. Social Indicators Research, 75: 273-302.

Chaskin, R. J. 1997. Perspectives on neighborhood and community: A review of the literature. The Social Service Review, 71: 521-547.

Chatterji, A. K., \& Toffel, M. W. 2010. How firms respond to being rated. Strategic Management Journal, 31: 917-945.

Coleman, J. S. 1988. Social capital in the creation of human capital. American Journal of Sociology, 94(Suppl.): S95-S120.

Coulton, C. J., Korbin, J. E., Su, M., \& Chow, J. 1995. Community level factors and child maltreatment rates. Child Development, 66: 1262-1276.

Dahlander, L., \& Magnusson, M. G. 2005. Relationships between open source software companies and communities: Observations from Nordic firms. Research Policy, 34: 481-493.

Davis, G. F., \& Greve, H. R. 1997. Corporate elite networks and governance changes in the 1980s. American Journal of Sociology, 103: 1-37.

Davis, G. F., McAdam, D., Scott, W. R., \& Zald, M. N. (Eds.). 2005. Social movements and organization theory. New York, NY: Cambridge University Press.

Deephouse, D. L. 1999. To be different, or to be the same? It's a question (and theory) of strategic balance. Strategic Management Journal, 20: 147-166.

DiMaggio, P. J., \& Powell, W. W. 1983. The iron cage revisited: Institutional isomorphism and collective rationality in organizational fields. American Sociological Review, 48: 147-160.

Dobbin, F., \& Dowd, T. 1997. How policy shapes competition: Early railroad foundings in Massachusetts. Administrative Science Quarterly, 42: 501-529.

Dobbin, F., \& Sutton, J. R. 1998. The strength of a weak state: The rights revolution and the rise of human 
resources management divisions. American Journal of Sociology, 104: 441-476.

Doh, J. P., \& Hahn, E. D. 2008. Using spatial methods in strategy research. Organizational Research Methods, 11: 659-681.

Doshi, A. R., Dowell, G. W. S., \& Toffel, M. W. 2013. How firms respond to mandatory information disclosure. Strategic Management Journal, 34: 1209-1231.

Drope, J. M., \& Hansen, W. L. 2006. Does firm size matter? Analyzing business lobbying in the United States. Business and Politics, 8: 1469-3569.

Durand, R., \& Jourdan, J. 2012. Jules or Jim: Alternative conformity to minority logics. Academy of Management Journal, 55: 1295-1315.

Durkheim, E. 1951. Suicide [Le suicide] (J. A. Spaulding, Trans., \& G. Simpson, Trans., Ed.). New York, NY: Free Press. (Original work published 1897).

Dyck, B., \& Schroeder, D. 2005. Management, theology and moral points of view: Towards an alternative to the conventional materialist-individualist ideal-type of management. Journal of Management Studies, 42: 705-735.

Edelman, L. B. 1990. Legal environments and organizational governance: The expansion of due process in the American workplace. American Journal of Sociology, 95: 1401-1440.

Elbannan, M., \& McKinley, W. 2006. A theory of the corporate decision to resist FASB standards: An organization theory perspective. Accounting, Organizations and Society, 31: 601-622.

European Commission. 2007. Attitudes of Europeans towards tobacco. Brussels, Belgium: European Commission.

Festinger, L. 1950. Informal social communication. Psychological Review, 57: 271-282.

Festinger, L., Schachter, S., \& Back, K. 1950. The spatial ecology of group formation. In L. Festinger, S. Schachter \& K. Back (Eds.), Social pressure in informal groups: A study of human factors in housing: 60-71. Stanford, CA: Stanford University Press.

Fiss, P. C., \& Zajac, E. J. 2004. The diffusion of ideas over contested terrain: The (non)adoption of a shareholder value orientation among German firms. Administrative Science Quarterly, 49: 501-534.

Forrest, R., \& Kearns, A. 2001. Social cohesion, social capital and the neighbourhood. Urban Studies (Edinburgh, Scotland), 38: 2125-2143.

Fox-Wolfgramm, S. J., Boal, K., \& Hunt, J. G. 1998. Organizational adaptation to institutional change: A comparative study of first-order change in prospector and defender banks. Administrative Science Quarterly, 43: 87-126.
Freeman, J. H., \& Audia, P. G. 2006. Community ecology and the sociology of organizations. Annual Review of Sociology, 32: 145-169.

Friedkin, N. E. 2004. Social cohesion. Annual Review of Sociology, 30: 409-425.

Glasmeier, A. 1991. Technological discontinuities and flexible production networks: The case of Switzerland and the world watch industry. Research Policy, 20: 469-485.

Gonzalez, M., \& Glantz, S. 2011. Failure of policy regarding smoke-free bars in the Netherlands. San Francisco, CA: Center for Tobacco Control Research and Education.

Goodstein, J. D. 1994. Institutional pressures and strategic responsiveness: Employer involvement in workfamily issues. Academy of Management Journal, 37: 350-382.

Goudriaan, H., Wittebrood, K., \& Nieuwbeerta, P. 2006. Neighbourhood characteristics and reporting crime: Effects of social cohesion, confidence in police effectiveness and socio-economic disadvantage. British Journal of Criminology, 46: 719-742.

Greenwood, R., \& Hinings, C. R. 1996. Understanding radical organizational change: Bringing together the old and the new institutionalism. Academy of Management Review, 21: 1022-1054.

Greenwood, R., Magan-Diaz, A., Li, S., \& Lorente, J. 2010. The multiplicity of institutional logics and the heterogeneity of organizational responses. Organization Science, 21: 521-539.

Greenwood, R., Oliver, C. E., Sahlin, K., \& Suddaby, R. 2008. Introduction. In R. Greenwood, C. Oliver, K. Sahlin \& R. Suddaby (Eds.), The Sage handbook of organizational institutionalism: 1-46. Thousand Oaks, CA: Sage.

Greve, H. R. 2002. An ecological theory of spatial evolution: Local density dependence in Tokyo banking, 1894-1936. Social Forces, 80: 847-879.

Guthrie, D. 2003. Survey on corporate-community relations. New York, NY: Social Sciences Research Council.

Guthrie, D., Arum, R., Roksa, J., \& Damaske, S. 2008. Giving to local schools: Corporate philanthropy, tax incentives, and the ecology of need. Social Science Research, 37: 856-873.

Hedström, P. 1994. Contagious collectivities: On the spatial diffusion of Swedish trade unions, 1890-1940. American Journal of Sociology, 99: 1157-1179.

Henriques, I., \& Sadorsky, P. 1996. The determinants of an environmentally responsive firm: An empirical approach. Journal of Environmental Economics and Management, 30: 381-395. 
Hilbe, J. 2007. Negative binomial regression. Cambridge, England: Cambridge University Press.

Hoetker, G. 2007. The use of logit and probit models in strategic management research: Critical issues. Strategic Management Journal, 28: 331-343.

Hoffman, A. J. 1999. Institutional evolution and change: Environmentalism and the U.S. chemical industry. Academy of Management Journal, 42: 351-371.

Horeca Nederland. 2008. Enquete invoering van het rookverbod 1 juni 2008 [Survey of implementation of smoking ban] (in Dutch). Woerden, the Netherlands: Koninklijke Horeca Nederland.

Ingram, P., \& Simons, T. 1995. Institutional and resource dependence determinants of responsiveness to workfamily issues. Academy of Management Journal, 38: 1466-1482.

Ingram, P., Yue, L. Q., \& Rao, H. 2010. Trouble in store: Probes, protests, and store opening by Wal-Mart, 1998-2007. American Journal of Sociology, 116: 53-92.

Janis, I. L. 1982. Groupthink. Boston, MA: Houghton Mifflin Company.

Jones, C., Boxenbaum, E., \& Anthony, C. 2013. The immateriality of material practices in institutional logics. Research in the Sociology of Organizations, 39A: 51-75.

Kasarda, J. D., \& Janowitz, D. 1974. Community attachment in mass society. American Sociological Review, 39: 328-339.

Kearns, A., \& Forrest, R. 2000. Social cohesion and multilevel urban governance. Urban Studies (Edinburgh, Scotland), 37: 995-1017.

Kim, T.-Y., Shin, D., Oh, H., \& Jeong, Y.-C. 2007. Inside the iron cage: Organizational political dynamics and institutional changes in presidential selection systems in Korean universities, 1985-2002. Administrative Science Quarterly, 52: 286-323.

Knoben, J., \& Oerlemans, L. A. 2012. Configurations of inter-organizational knowledge links: Does spatial embeddedness still matter? Regional Studies, 46: 1005-1021.

Knoben, J., Ponds, R., \& van Oort, F. 2011. Employment from new firm formation in the Netherlands: Agglomeration economies and the knowledge spillover theory of entrepreneurship. Entrepreneurship $\boldsymbol{\&} \boldsymbol{R e}-$ gional Development, 23: 135-157.

Lamont, M., \& Molnar, V. 2002. The study of boundaries in the social sciences. Annual Review of Sociology, 28: 167-195.

Lashley, C. 2000. In search of hospitality: Towards a theoretical framework. Hospital Management, 19: 3-15.
Lawrence, T. B. 2008. Power, institutions and organizations. In R. Greenwood, C. Oliver, K. Sahlin \& R. Suddaby (Eds.), The Sage handbook of organizational institutionalism: 170-197. Thousand Oaks, CA: Sage.

Leicht, K. T., \& Jenkins, J. C. 1998. Political resources and direct state intervention: The adoption of public venture capital programs in the American states, 1974-1990. Social Forces, 76: 1323-1345.

Lepoutre, J. M. W. N., \& Valente, M. 2012. Fools breaking out: The role of symbolic and material immunity in explaining institutional nonconformity. Academy of Management Journal, 55: 285-313.

Levy, D., \& Scully, M. 2007. The institutional entrepreneur as modern prince: The strategic face of power in contested fields. Organization Studies, 28: 971-991.

Long, S. 1997. Regression models for categorical and limited dependent variables. Thousand Oaks, CA: Sage.

Lounsbury, M. 2007. A tale of two cities: Competing logics and practice variation in the professionalizing of mutual funds. Academy of Management Journal, 50: 289-307.

Lounsbury, M., Ventresca, M., \& Hirsch, P. M. 2003. Social movements, field frames and industry emergence: A cultural-political perspective on U.S. recycling. Socio-economic Review, 1: 71-104.

Mariotti, F., \& Delbridge, R. 2012. Overcoming network overload and redundancy in interorganizational networks: The roles of potential and latent ties. Organization Science, 23: 511-528.

Marquis, C., \& Battilana, J. 2009. Acting globally but thinking locally? The enduring influence of local communities on organizations. Research in Organizational Behavior, 29: 283-302.

Marquis, C., Glynn, M. A., \& Davis, G. F. 2007. Community isomorphism and corporate social action. Academy of Management Review, 32: 925-945.

Marquis, C., \& Lounsbury, M. 2007. Vive la résistance: Competing logics and the consolidation of U.S. community banking. Academy of Management Journal, 50: 799-820.

Marquis, C., Lounsbury, M., \& Greenwood, R. 2011. Introduction: Community as an institutional order and a type of organizing. In C. Marquis, M. Lounsbury, \& R. Greenwood (Eds.), Communities and organizations (Research in the sociology of organizations, vol. 33): ix-xxvii. Bingley, England: Emerald Group Publishing.

Marquis, C., \& Qian, C. 2014. Corporate social responsibility reporting in China: Symbol or substance? Organization Science, 25: 127-148.

Marti, I., \& Fernandez, P. 2013. The institutional work of oppression and resistance: Learning from the Holocaust. Organization Studies, 34: 1195-1223. 
McPherson, M., \& Smith-Lovin, L. 2002. Cohesion and membership duration: Linking groups, relations and individuals in an ecology of affiliation. Advances in Group Processes, 19: 1-36.

Molina-Morales, F. X., \& Martínez-Fernández, M. T. 2009. Too much love in the neighborhood can hurt: How an excess of intensity and trust in relationships may produce negative effects on firms. Strategic Management Journal, 30: 1013-1023.

Molotch, H., Freudenburg, W., \& Paulsen, K. E. 2000. History repeats itself, but how? City character, urban tradition, and the accomplishment of place. The Sociological Review, 65: 791-823.

Moody, J., \& White, D. R. 2003. Structural cohesion and embeddedness: A hierarchical concept of social groups. American Sociological Review, 68: 103-127.

Morenoff, J. D., Sampson, R. J., \& Raudenbush, S. W. 2001. Neighborhood inequality, collective efficacy, and the spatial dynamics of urban violence. Criminology, 39: 517-558.

Nagelhout, G. E., van den Putte, B., de Vries, H., Crone, M., Fong, G. T., \& Willemsen, M. C. 2011. The influence of newspaper coverage and a media campaign on smokers' support for smoke-free bars and restaurants and on secondhand smoke harm awareness: Findings from the International Tobacco Control (ITC) Netherlands survey. Tobacco Control, 21: 24-29.

OECD. 2010. Health at a glance: Europe, 2010. Paris, France: Organisation for Economic Co-operation and Development.

Okhmatovskiy, I., \& David, R. J. 2012. Setting your own standards: Internal corporate governance codes as a response to institutional pressure. Organization Science, 23: 155-176.

Oliver, C. 1991. Strategic responses to institutional processes. Academy of Management Review, 16: 145-179.

Plantinga, M., de Ridder, K., \& Corra, A. 2011. Choosing whether to buy or make: The contracting out of employment reintegration services by Dutch municipalities. Social Policy and Administration, 45: 245-263.

Portes, A., \& Sensenbrenner, J. 1993. Embeddedness and immigration: Notes on the social determinants of economic action. American Journal of Sociology, 98: 1320-1350.

Putnam, R. 2000. Bowling alone: The collapse and revival of American community. New York, NY: Simon \& Schuster.

Quirke, L. 2013. Rogue resistance: Sidestepping isomorphic pressures in a patchy institutional field. Organization Studies, 34: 1675-1699.

Rao, H., Morrill, C., \& Zald, M. N. 2000. Power plays: How social movements and collective action create new organizational forms. Research in Organizational Behavior, 22: 239-282.

Sampson, R. J. 1988. Local friendship ties and community attachment in mass society: A multilevel systemic model. American Sociological Review, 53: 766-779.

Sampson, R. J. 1991. Linking the micro- and macro-level dimensions of community social organization. Social Forces, 70: 43-64.

Sampson, R. J., McAdam, D., MacIndoe, H., \& WefferElizondo, S. 2005. Civil society reconsidered: The durable nature and community structure of collective civic action. American Journal of Sociology, 111: 673-714.

Schneiberg, M., \& Bartley, T. 2001. Regulating American industries: Markets, politics, and the institutional determinants of fire insurance regulation. American Journal of Sociology, 107: 101-146.

Schneiberg, M., King, M., \& Smith, T. 2008. Social movements and organizational form: Cooperative alternatives to corporations in the American insurance, dairy, and grain industries. American Sociological Review, 73: 635-667.

Slack, T., \& Hinings, C. R. 1994. Institutional pressures and isomorphic change: An empirical test. Organization Studies, 15: 803-827.

Small, M. L. 2002. Culture, cohorts, and social organization theory: Understanding local participation in a Latino housing project. American Journal of Sociology, 108: $1-54$.

Spinney, L. 2007. Public smoking bans show signs of success in Europe. Lancet, 369: 1507-1508.

Starkey, K., Barnatt, C., \& Tempest, S. 2000. Beyond networks and hierarchies: Latent organizations in the UK television industry. Organization Science, 11: 299-305.

Stichting Horecaclaim Nederland. 2009. Message posted to KHO Stichting "Red de Kleine Horeca-ondernemer" [KHO Foundatation "Save the Small Hospitality Entrepreneur”] http://www.kleinehoreca.info/home. Accessed January 2010.

Synovate. 2008. Rapport: Onderzoek effecten rookvrije horeca (81303) [Report: Research on the effects of a smoke-free hospitality industry] (in Dutch). Amsterdam, The Netherlands: Synovate.

Thomas, R., \& Davies, A. 2005. Theorizing the micropolitics of resistance: New public management and managerial identities in the UK public services. Organization Studies, 26: 683-706.

Thornton, P. H., \& Ocasio, W. 1999. Institutional logics and the historical contingency of power in organizations: Executive succession in the higher education publishing industry, 1958-1990. American Journal of Sociology, 105: 801-843. 
Tilcsik, A., \& Marquis, C. 2013. Punctuated generosity: How mega-events and natural disasters affect corporate philanthropy in U.S. communities. Administrative Science Quarterly, 58: 111-148.

Tolbert, P. S., \& Zucker, L. G. 1983. Institutional sources of change in the formal structure of organizations: The diffusion of civil service reform, 1880-1935. Administrative Science Quarterly, 28: 22-39.

Tolsma, J., van der Meer, T., \& Gesthuizen, M. 2009. The impact of neighbourhood and municipality characteristics on social cohesion in the Netherlands. Acta Politica, 44: 286-313.

Tönnies, F. 1957. Community and society [Gemeinschaft und Gesellschaft] (C. P. Loomis, Trans., Ed.). New York, NY: Harper. (Original work published 1887).

Torre, A., \& Gilly, J. P. 2000. On the analytical dimension of proximity dynamics. Regional Studies, 34: 169-180.

Useem, M. 1988. Market and institutional factors in corporate contributions. California Management Review, 30: 77-88.

Uzzi, B. 1996. The sources and consequences of embeddedness for the economic performance of organizations: The network effect. American Sociological Review, 61: 674-698.

van Tubergen, F., te Grotenhuis, M., \& Ultee, W. 2005. Denomination, religious context, and suicide: NeoDurkheimian multilevel explanations tested with individual and contextual data. American Journal of Sociology, 111: 797-823.

Verbeek, M. 2004. A guide to modern econometrics (2nd ed.). Chichester, England: John Wiley \& Sons.

Vermeulen, P. A. M., Büch, R., \& Greenwood, R. 2007. The impact of governmental policies in institutional fields: The case of innovation in the concrete industry. Organization Studies, 28: 515-540.

VROM. 2009. Het wonen overwogen: Resultaten van het WoonOnderzoek Nederland 2009 [Living Experience: Results of the Housing Survey of the Netherlands 2009] (in Dutch). The Hague, the Netherlands: VROM/CBS.

VWA. 2008. Inspectieresultaten rookvrije horeca; juli t/m september 2008 [Inspection results: Smoke-free hospitality venues, July-September 2008] (in Dutch). The Hague, the Netherlands: VWA.

VWA. 2010. Inventarisatie naleefniveau rookvrije horeca zomer 2010 [Inventory: Smoke-free hospitality venues, summer 2010] (in Dutch). The Hague, the Netherlands: VWA.

VWA. 2012. Inventarisatie naleefniveau rookvrije horeca voorjaar 2012 [Inventory: Smoke-free hospitality venues, spring 2012] (in Dutch). The Hague, the Netherlands: VWA.

Waldorff, S. B., \& Greenwood, R. 2011. The dynamics of community translation: Danish health-care centres. In C. Marquis, M. Lounsbury, \& R. Greenwood (Eds.) Communities and organizations (Research in the sociology of organizations, vol. 33): 113-142. Bingley, England: Emerald Group Publishing.

Wolfson, M. 2001. The fight against tobacco: The movement, the state, and the public's health. New York, NY: Aldine de Gruyter.

Zukin, S., \& DiMaggio, P. 1990. The social organization of the economy. Cambridge, England: Cambridge University Press.

\section{$M$}

Tal Simons (t.simons@tilburguniversity.edu) is a professor in the Department of Management (Organization \& Strategy) at the Tilburg School of Economics and Management in the Netherlands. She received her PhD from Cornell University. Her research interests mainly concern the dynamics of persistence and change of organizations, organizational forms, populations, and categories. These are examined in a variety of contexts, such as contested industries and the creative sector among others.

Patrick Vermeulen (p.vermeulen@fm.ru.nl) is a full professor of strategy and international management at the Institute for Management Research of Radboud University in the Netherlands. He also received his PhD from Radboud University. His research interests include institutional change and institutional complexity, as well as innovation in developing countries.

Joris Knoben (j.knoben@fm.ru.nl) is a full professor of business economics at the Institute for Management Research, Radboud University. He received his $\mathrm{PhD}$ from Tilburg University. His research focuses on the two-way interaction between the external environment of organizations and their behavior and performance. 